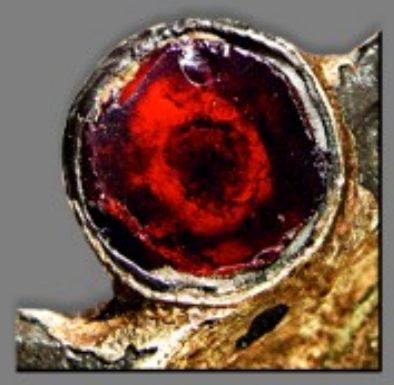

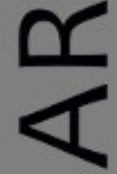

$\sim$

ш
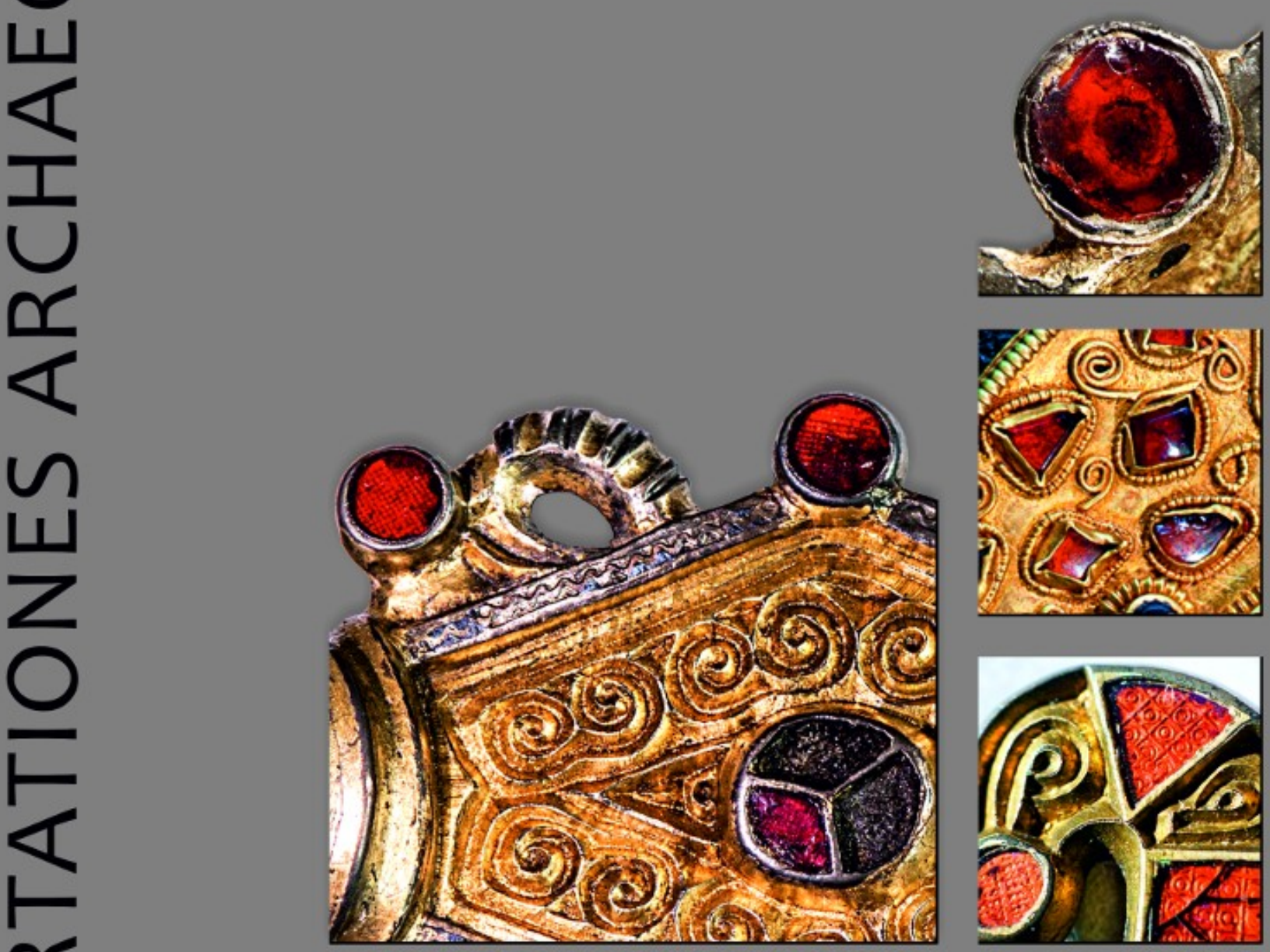

E

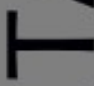

œ

山

n

ก

$\overline{0}$
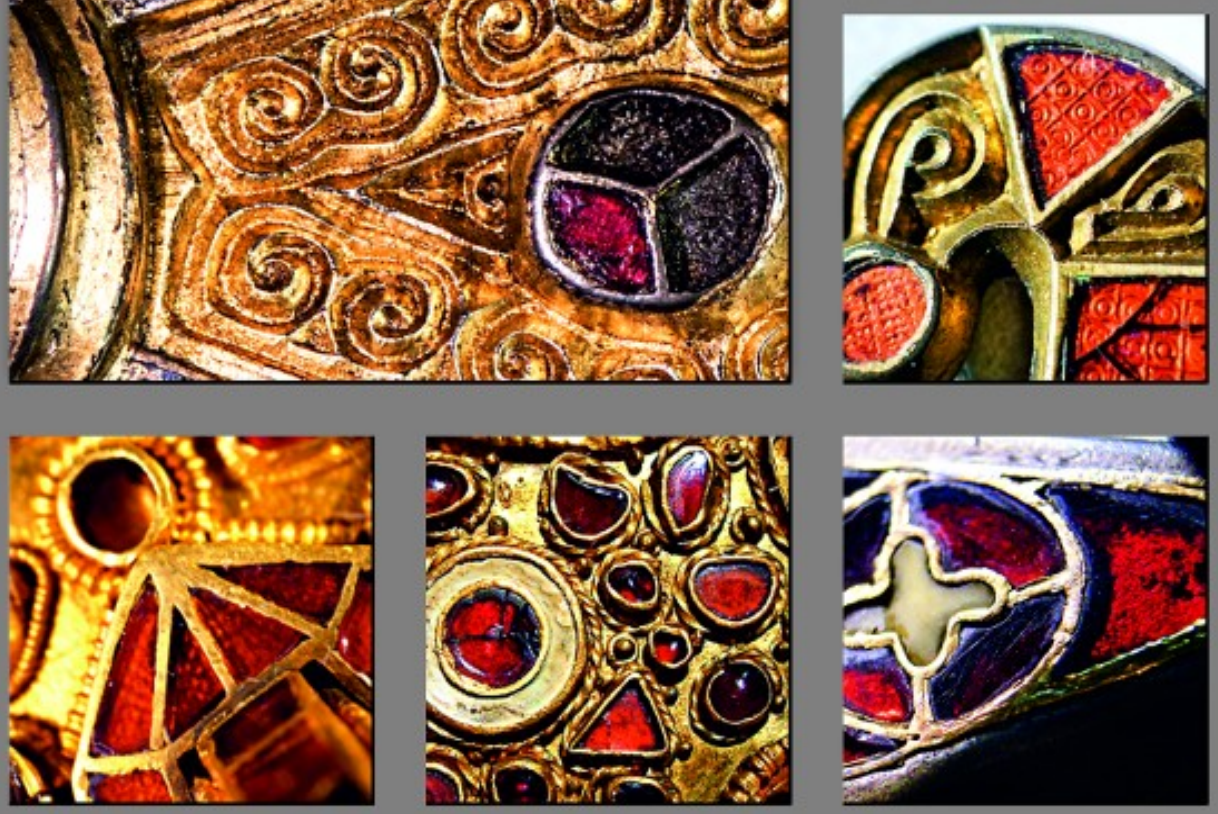

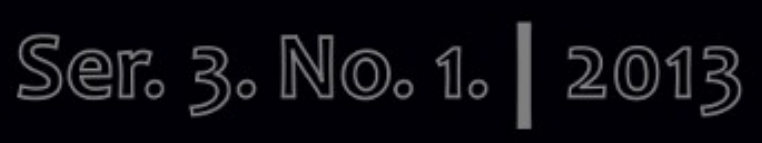




\section{Dissertationes Archaeologicae ex Instituto Archaeologico}

Universitatis de Rolando Eötvös nominatae Ser. 3. No. 1.

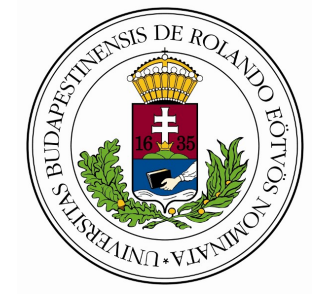

Budapest 2013 
Dissertationes Archaeologicae ex Instituto Archaeologico

Universitatis de Rolando Eötvös nominatae

Ser. 3. No. 1.

Editor-in-chief:

DÁvid BARTUS

Editorial board:

LÁSZLÓ BARTOSIEWICZ

LÁSZLÓ BORHY

ISTVÁN FELD

GÁBOR KALLA

PÁL RACZKY

Miklós SzABÓ

TIVADAR VIDA

Technical editors:

DÁvid BARTuS

GÁBOR VÁCZI

ANDRÁs BöDŐcs

Proofreading:

Zsófia KondÉ

SzILvia SzÖLlősI

Available online at http://dissarch.elte.hu

Contact: dissarch@btk.elte.hu

\section{$\underline{\text { PKP }}$ \\ PUBLIC \\ KNOWLEDGE \\ PROJECT}

(C) Eötvös Loránd University, Institute of Archaeological Sciences

Budapest 2013 


\section{Contents}

\section{Articles}

Melinda TORBÁGYI - István VIDA

The coin hoard of Abasár

Anikó BózsA

21

Roman mirrors from a private collection in the Hungarian National Museum

Lajos JuHÁsz

45

The Biesheim cameo - a reinterpretation

\section{Methods}

Péter CsIPpÁN

$A z$ állatcsont, mint információhordozó leletanyag

Kata DÉvAI

Terminológiai alapfogalmak régészeti korú üvegtárgyak elemzéséhez

Lőrinc TimáR - Zoltán Czajlik - Sándor Puszta - Balázs Holl

$3 D$ reconstructions using GPR data at the Mont Beuvray

\section{FIELD REPORTS}

Zsolt MESTER

Excavation at a new Upper Palaeolithic site of the Eger region (Northern Hungary)

László BORHY - Dávid BARTus - Emese SzÁmadó

Short report on the excavations at Brigetio (Szőny-Vásártér) in 2013

Dénes HulLÁm - Zsófia RÁcz

Report on the participation of the Eötvös Loránd University at the Wielbark Archaeological Field School in Malbork-Wielbark, Poland

Gábor VÁczi - Dávid BARTus

Short report on the excavations at the site Makó - Igási Ugar

Maxim MoRdovin

Short report on the excavations in 2013 of the Department of Hungarian Medieval and Early Modern Archaeology (Eötvös Loránd University, Budapest)

\section{THESIS ABSTRACTS}

Kitti KÖHLER

Biological reconstruction of the Late Neolithic Lengyel Culture 
Cultural connections and interactions of Eastern Transdanubia during the Urnfield period

Orsolya LÁNG

Urban problems in the civil town of Aquincum: the so-called „northern band”

Nikoletta SEY

Questions of bronze workshops in Roman Pannonia

Kata DÉvaI

Glass vessels from Late Roman times found in graves in the Hungarian part of Pannonia

Eszter HORvÁTH

Gemstone and glass inlaid fine metalwork from the Carpathian Basin:

the Hunnic and Early Merovingian Periods

Gergely SzEnTHE

Vegetal ornaments in the Late Avar decorative art

Péter LANGó

Relations between the Carpathian Basin and South East Europe during the 10th century.

The evidence of the minor objects

Ciprián HoRvÁTH

The Cemeteries and Grave Finds of Györ and Moson Counties from the Time

of the Hungarian Conquest and the Early Árpádian Age

András Sófalvi

The border- and self-defence of Szeklers from the Medieval Age till the Age of Principality.

Castles and other defence objects in the settlement history of Udvarhelyszék 


\title{
Biological reconstruction of the Late Neolithic Lengyel Culture
}

\section{KITTI KÖHLER}

Research Center for the Humanities, Institute of Archaeology

Hungarian Academy of Sciences

kohler.kitti@btk.mta.hu

kohler.kitti@gmail.com

\begin{abstract}
PhD thesis submitted in 2013 to the Doctoral School of Biology, Eötvös Loránd University, Budapest under the supervision of Gyula Gyenis.

Between 2006 and 2009 rescue excavations preceding the construction of M6 Motorway were carried out, in the course of which a settlement and a related cemetery of more than two thousand graves of the Late Neolithic-Early Copper Age Lengyel culture have been excavated at the site of Alsónyék-Bátaszék, in Southeastern Transdanubia (Tolna county). Present study considers the northern, so-called 010/B part of the site (cemetery), comprising 862 graves. According to the current archaeological consensus earlier Central European Linearbandkeramik culture (LBK) played a crucial role in the formation of the Lengyel culture, but an infiltration or migration of new populations during this time period cannot be excluded. Present dissertation has been designed to investigate this fundamental question. In addition, I completed a detailed demographic analysis and published the frequency data of several pathological and dental alterations. In the course of the still ongoing investigation a case showing the classic symptoms of tuberculosis had been found.
\end{abstract}

\section{Introduction}

The physical anthropological characteristics of the Transdanubian Late Neolithic-Early Copper Age Lengyel culture are well known due to its numerous excavated cemeteries (Fig 1), which were investigated by physical anthropologists, and the majority of them was published by K. Zoffmann. ${ }^{1}$ According to current archaeological consensus the earlier Central European Linearbandkeramik culture (LBK) played a crucial role in the formation of the culture, which is supported by their identical geographical distribution. ${ }^{2}$ However, southern and southeastern influences archaeologically detected in the material culture suggest an infiltration of new populations during this time period. ${ }^{3}$ Considering the origin of Lengyel people the physical anthropological literature identifies multiple scenarios that differ in the assumed ratios of indigenous and infiltrated populations. ${ }^{4}$ Present dissertation has been designed to investigate this fundamental question, based on the morphometric, taxonomic and craniometric comparative analyses of the human remains unearthed at the site of Alsónyék Bátaszék. In addition, pathology and the dental alterations were also observed and frequency data published, which will contribute to further comparative investigations. ${ }^{5}$

1 K. ZofFMANn 1968; 1969-1970; 2004; 2012.

2 KalicZ 1988.

3 KALICZ 2001.

4 SZATHMÁry 1980; 1981; ZoffmAnn 2004; KőVÁRI - SZATHMÁRY 2001; KöVÁRI 2008.

5 PAP 2012. 


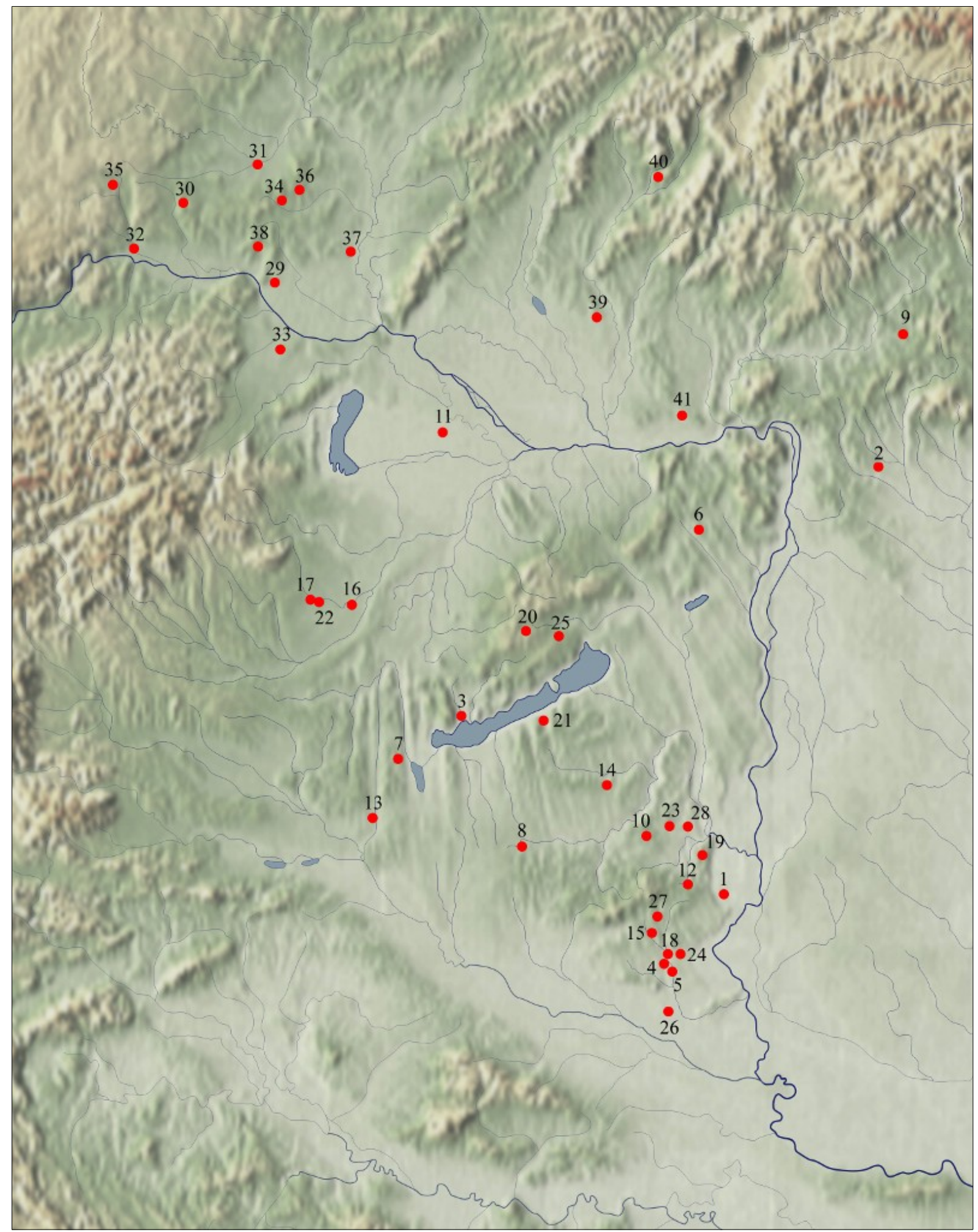

Fig. 1. Anthropologically known Lengyel sites in the Carpathian Basin (Cs. Peterdi - Zs. Réti - K. Köhler). 
Biological reconstruction of the Late Neolithic Lengyel Culture

\begin{tabular}{|c|c|c|c|c|c|c|}
\hline Sites & Inf. & $\widehat{0}$ & 우 & $?$ & Total & Literature \\
\hline \multicolumn{7}{|l|}{ Hungary } \\
\hline 1. Alsónyék-Bátaszék & 147 & 248 & 336 & 131 & 862 & Present thesis. \\
\hline 2. Aszód-Papi földek & 78 & 48 & 72 & 2 & 204 & K. ZOFFMANN 2014. \\
\hline 3. Balatonederics-Döme barlang & - & 1 & - & - & 1 & BERNERT ET AL. 2002. \\
\hline 4. Belvárdgyula-Szarkahegy & 6 & 3 & 7 & - & 16 & K. ZOFFMANN, unpublished. \\
\hline 5. Borjád-Kenderföld & - & - & 1 & - & 1 & K. ZoFfmanN, unpublished. \\
\hline 6. Csabdi-Télizöldes & 11 & 7 & 15 & 1 & 34 & KÖHLER 2004. \\
\hline 7. Esztergályhorváti & - & 38 & - & - & 38 & K. ZOFFMANN 2007. \\
\hline 8. Kaposújlak-Várdomb & - & - & 1 & - & 1 & K. ZOFFMANN 2011. \\
\hline 9. Karancsság & - & - & 2 & - & 2 & KÖHLER 2003. \\
\hline 10. Lengyel & 1 & 5 & - & - & 6 & VIRCHOW 1890; MALÁN 1929. \\
\hline 11. Lébény-Kaszásdomb & - & 1 & - & - & 1 & K. ZOFFMANN 1998-1999. \\
\hline 12. Mórágy-Túzkődomb B.1 & 34 & 14 & 31 & 3 & 82 & K. ZOFFMANN 2004. \\
\hline Mórágy-Tüzkődomb B.2 & 12 & 5 & 9 & - & 26 & K. ZOFFMANN 2013. \\
\hline 13. Nagykanizsa-Palin & 1 & 1 & 2 & 2 & 6 & То́тн 2009; 2011. \\
\hline 14. Pári-Altacker & 3 & 4 & 4 & - & 11 & KisZely 1973. \\
\hline 15. Pécsvárad-Aranyhegy & $?$ & $?$ & $?$ & $?$ & 8 & K. ZOFFMANN 1998-1999. \\
\hline 16. Sárvár, elkerülő út, 5 . lh. & - & 1 & - & - & 1 & То́тн 2002. \\
\hline 17. Sé-Malomi dűlő and Sé-Doberdó & 1 & 1 & - & - & 2 & Tо́тн 1996-1997, 2002. \\
\hline 18. Szederkény-Kukorica-dűlő & 1 & 2 & 1 & - & 4 & K. ZOFFMANN, unpublished. \\
\hline 19. Szekszárd-Ágostonpuszta & 1 & 13 & 6 & 2 & 22 & NEMESKÉRI 1955. \\
\hline 20. Szentgál-Füzikút & - & - & 1 & 1 & 2 & K. ZOFFMANN 1998-1999. \\
\hline 21. Szólád-Kisaszó & 2 & - & 1 & - & 3 & KöHLER, unpublished. \\
\hline 22. Szombathely, Metró Áruház & 1 & - & - & - & 1 & То́тн 2002. \\
\hline 23. Tevel-Zsidóhegy & - & 1 & 1 & - & 2 & K. ZoFfmANN 1998-1999. \\
\hline 24. Versend-Gilencsa & - & - & 2 & - & 2 & K. ZOFFMANN, unpublished. \\
\hline 25. Veszprém, Jutasi út & 2 & 5 & 5 & 1 & 13 & KÖHLER 2006. \\
\hline 26. Villánykövesd & 9 & 9 & 4 & 1 & 23 & K. ZOFFMANN 1968. \\
\hline 27. Zengővárkony & 4 & 25 & 33 & 2 & 64 & K. ZOFFMANN 1969-1970. \\
\hline 28. Zomba-Paradicsompuszta & $?$ & $?$ & $?$ & $?$ & 4 & NEMESKÉRI 1955. \\
\hline \multicolumn{7}{|l|}{ Austria } \\
\hline 29. Bisamberg & - & - & 1 & - & 1 & JUNGWIRTH 1956. \\
\hline 30. Eggenburg & - & 1 & - & - & 1 & EHGARTNER 1956. \\
\hline 31. Friebritz-Süd & 5 & 5 & 1 & 1 & 12 & $\begin{array}{l}\text { NEUGEBAUER - MARESCH - } \\
\text { Teschler-Nicola } 2006 .\end{array}$ \\
\hline 32. Langenlois & - & - & 2 & - & 2 & ZIMMERMANN 1935. \\
\hline 33. Mauer & 2 & 2 & 3 & - & 7 & STROUHAL - JUNGWIRTH 1970. \\
\hline 34. Mödling & - & - & 2 & - & 2 & RuttKay - Teschler-Nicola 1985. \\
\hline 35. Poigen & 1 & 1 & 3 & - & 5 & EHGARTNER - JUNGWIRTH 1956. \\
\hline 36. Poysdorf & - & 2 & - & - & 2 & JUNGWIRTH 1967. \\
\hline
\end{tabular}




\begin{tabular}{|l|c|c|c|c|c|l|}
\hline \multicolumn{1}{|c|}{ Sites } & Inf. & $\boldsymbol{\sigma}$ & O & $?$ & Total & \multicolumn{1}{|c|}{ Literarure } \\
\hline 37. Stillfried & - & 1 & - & - & $\mathbf{1}$ & SCHÜRER v. WALDHEIM 1919. \\
\hline 38. Wetzleinsdorf & - & - & 1 & - & $\mathbf{1}$ & JUNGWIRTH 1973. \\
\hline Slovakia & 1 & 1 & 1 & 2 & $\mathbf{5}$ & VLČEK 1961. \\
\hline 39. Lužianky & - & - & 1 & - & $\mathbf{1}$ & VLČEK - BARTA 1950. \\
\hline 40. Malé Krštenany & 42 & 23 & 27 & 6 & $\mathbf{9 8}$ & JAKAB 1986. \\
\hline 41. Svodín &
\end{tabular}

\section{Material}

Between 2006 and 2009 rescue excavations preceding the construction of M6 Motorway were carries out, in the course of which a Lengyel settlement and a related cemetery of nearly 2400 graves have been excavated at the site of Alsónyék-Bátaszék, in Southeastern Transdanubia. ${ }^{6}$ Since the total size of the site and the correlation of different parts of the cemetery and adjacent settlement was not yet known at the time when I worked on my dissertation and only became clear later, the physical anthropological analysis and evaluation of the whole community was not feasible within the frames of the dissertation. Therefore, present study considers the northern, so-called 010/B part of the cemetery comprising 862 graves (Fig. 2-3). The results of this analysis, despite the fact that it was not based on the whole series, may significantly modify our recent knowledge on the population of the Lengyel culture.

\section{Methods}

For the biological age estimation of the subadults I used methodologies outlined by Schour and Massler, Stloukal and Hanáková, Ferembach et al., Schinz et al., Ubelaker and Bernert et al. ${ }^{7}$ The age estimation of adults was carried out on the basis of Todd, Nemeskéri et al., Szilvássy , Işcan et al. and Meindl - Lovejoy. ${ }^{8}$ The morphological sex was described by the method of Éry et al. ${ }^{9}$ The demographic analysis was carried out on the basis of Acsádi and Nemeskéri. ${ }^{10}$ The anatomical variation was examined according to Finnegan, Hauser - De Stefano and Saunders. ${ }^{11}$ The metric and the morphological evaluation was based on Martin Saller and Alekseiev - Debets' method. ${ }^{12}$ Stature was estimated using the work of PearsonRösing, Sjøvold and Bernert. ${ }^{13}$ Taxonomical analyses were mainly carried out by the method of Lipták. ${ }^{14}$ The craniometric comparative examinations of the male and female series were based on 10 measurements of the skulls, which were standardized with the average standard deviations of Alekseiev and Debets. ${ }^{15}$ I applied the direct distance values between the examined series in the course of the comparison, and used the Euclidean, Chebyshev, Penrose distance and the Pearson's correlation coefficient. ${ }^{16}$ I analyzed the limit of the significant simi-

6 Zalai-GaÁl - Osztás 2009; Gallina et Al. 2010.

7 Schour - Massler 1941; Stloukal - HanÁková 1978; Ferembach et Al. 1979; Schinz et al. 1952; Ubelaker 1989; BERNERT ET AL. 2007.

8 Todd 1920; Nemeskéri ET AL. 1960; Miles 1963; Szilvássy 1978; IşCAn Et Al. 1985; MeindL - Lovejoy 1985.

9 ÉRY ET AL. 1963.

10 ACSÁdi - NEMESKÉRI 1970.

11 Finnegan 1972; Hauser - De Stefano 1989; SAunders 1978.

12 Martin - Saller 1957; Alekseiev - Debets 1964.

13 Pearson - Rösing 1988; Sjøvold 1990; Bernert 2005.

14 LIPTÁK 1962; 1965.

15 Alekseiev - Debets 1964.

16 Penrose 1954; Rahmann 1962. 
larity at $0.1,0.5$ and $1 \%$ significance level in every distance calculating method. The pathological investigation was based on the systematization according to Steinbock. ${ }^{17}$ During the analysis of oral pathologies I recorded the number of premortem tooth loss, cavities, alveolar abscesses and dental hypoplasia.

\section{Objectives}

In the dissertation I sought to answer the following questions:

- How did the demographic composition of the community of Alsónyék look like? Do the demographic characteristics of the analyzed sample resemble those observed in other series of the Lengyel culture?

- As a characteristic of the Lengyel mortuary practices, graves are usually found in smaller or larger grave groups occupying unused territories of the settlement. The research assumes that such spatial distributional patterns may correlate with affinal relations between the deceased..$^{18}$ Based on the demographic characteristics and on the heritable anatomical variations of the skeletal remains, is it possible to verify the family relationships of the deceased in these groups?

- What was the anthropological image characterizing the populations of the Lengyel culture? How does the physical anthropological analysis of this large sample affect or alter our recent knowledge of the Lengyel populations?

- Is it possible to demonstrate an anthropological continuity between the population of the Lengyel culture and the earlier inhabitants that occupied the same territory? Can we verify the assumed continuity between populations of earlier Neolithic periods, or do we need to calculate with a population infiltration or migration during the Late Neolithic in Transdanubia?

- What are the differences or similarities between the anthropological physiognomy of populations occupying the Eastern and Western Carpathian Basin and living in the same Late Neolithic period?

- What was the general state of health of the Alsónyék community? What diseases occurred most frequently within the population? How does it inform us about their lifestyle?

- What was the oral pathological status of the community of Alsónyék? How does it inform us about their diet and way of life?

- Do the anthropological characteristics of individuals buried in graves resting on four wooden pillars and containing a large amount of high quality grave-goods show any difference from the average individuals buried in simple graves? Can we see any anthropological physiognomy or pathological difference suggesting alternative lifestyle, diet, or different origin marking their distinctive position within the community?

17 STEINBOCK 1976.

18 But it is imaginable that it has been arranged on domestic units, or they were created simply by burying next to each other those who died around the same time at the same place. 


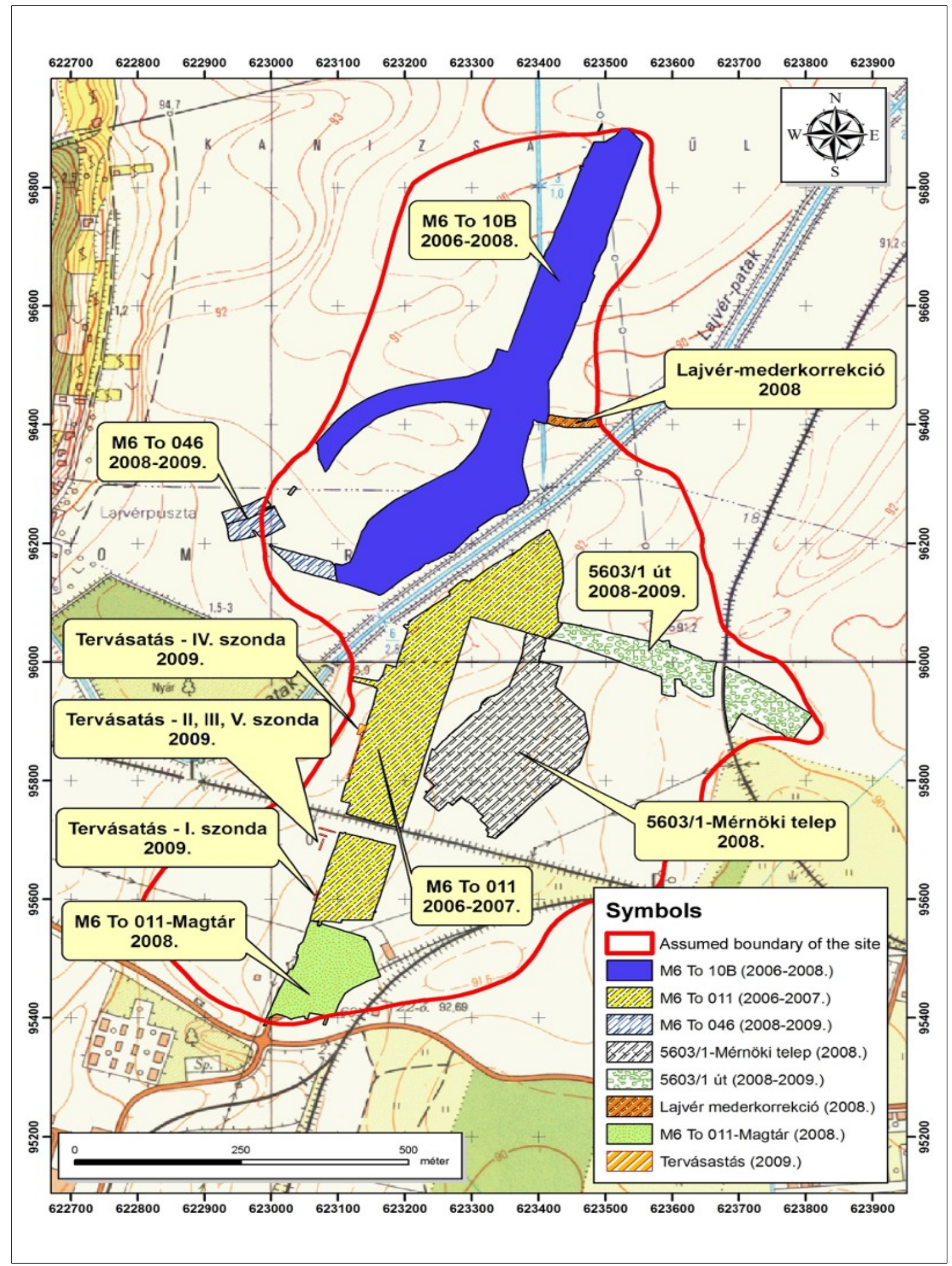

Fig. 2. Map of the site with the so-called 010/B part of the cemetery marked in blue (Archaeosztráda Ltd.). 


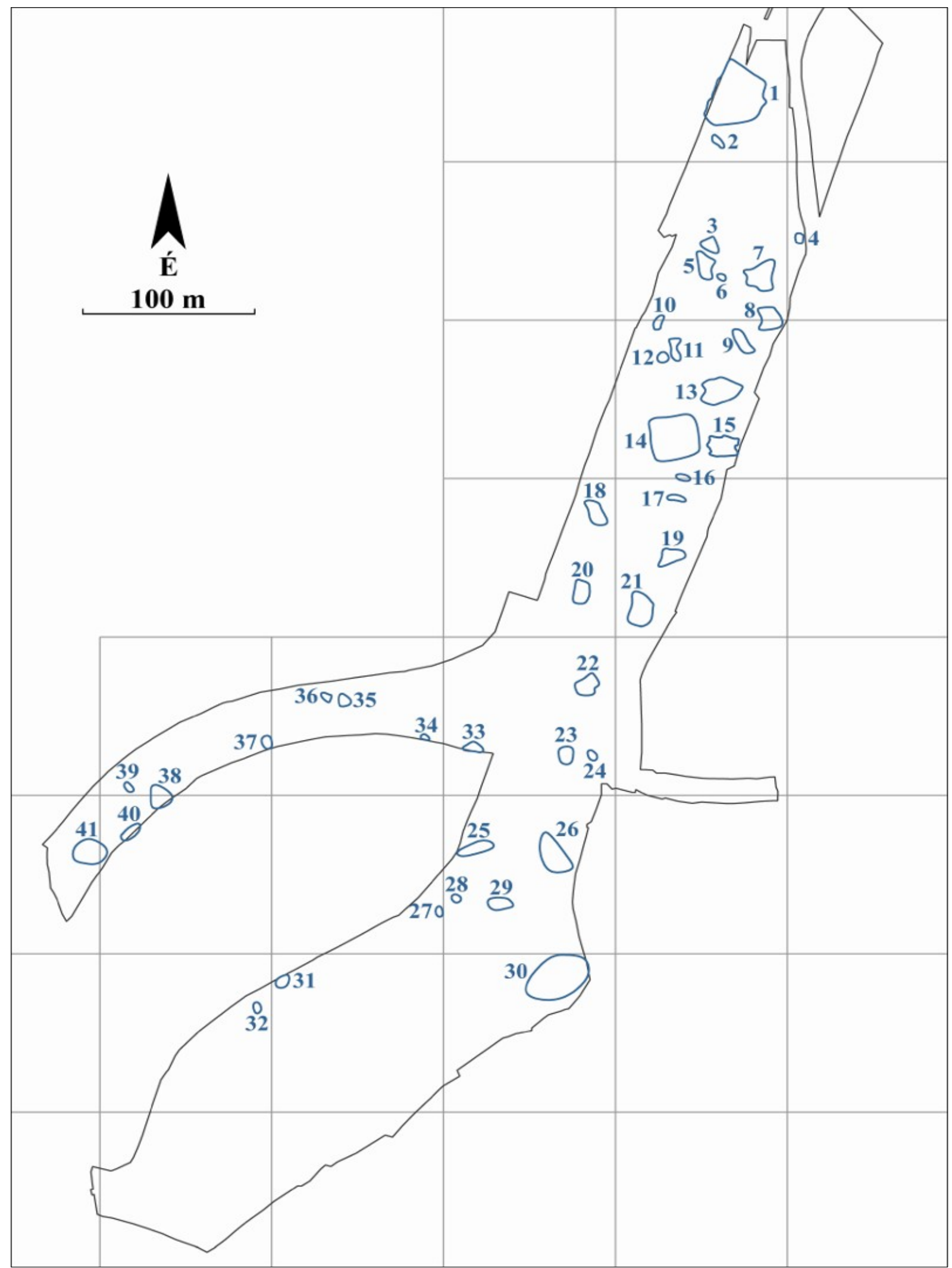

Fig. 3. Burial groups in the excavated 10/B area (Â. Marton). 


\section{Results and conclusions}

Following the questions and goals of the present dissertation the results of the physical anthropological analysis of the skeletal material from Alsónyék can be summarized as follows.

According to the demographic analysis, the population of the Alsónyék community was blessed with unrealistic mortality parameters. Despite to previous expectations, the ratio of neonates $( \pm 0)$ is merely $1 \%$, consequently the life expectancy at birth $\left(e_{x}{ }^{0}\right)$ is rather high (32.61 years). The proportion of infant I. and II. is also low (9.1\% and 8.0\%). In the meantime, contrary to the expected value, the ratio of adult and mature-aged individuals is almost equal $(36.7 \%$ and $36.8 \%$ respectively), while senile-aged individuals are practically missing from the cemetery (0.2\%) (Fig. 4).

\begin{tabular}{|l|c|c|c|c|}
\hline \multicolumn{1}{|c|}{ Age/Sex } & $\boldsymbol{2}$ & Male & Female & Total \\
\hline Neonatus & 9 & 0 & 0 & $\mathbf{9}$ \\
\hline Infans I. & 65 & 0 & 0 & $\mathbf{6 5}$ \\
\hline Infans I.-II. & 7 & 0 & 0 & $\mathbf{7}$ \\
\hline Infans II. & 65 & 0 & 0 & $\mathbf{6 5}$ \\
\hline Infans II.-Fuvenis & 2 & 0 & 0 & $\mathbf{2}$ \\
\hline fuvenis & 38 & 7 & 12 & $\mathbf{5 7}$ \\
\hline fuvenis-Adultus & 3 & 3 & 6 & $\mathbf{1 2}$ \\
\hline Adultus & 27 & 95 & 140 & $\mathbf{2 6 2}$ \\
\hline Adultus-Maturus & 19 & 32 & 46 & $\mathbf{9 7}$ \\
\hline Maturus & 28 & 109 & 130 & $\mathbf{2 6 7}$ \\
\hline Maturus-Senilis & 0 & 1 & 2 & $\mathbf{3}$ \\
\hline Senilis & 0 & 0 & 0 & $\mathbf{0}$ \\
\hline Adultus-Senilis & 9 & 1 & 0 & $\mathbf{1 0}$ \\
\hline$?$ & 6 & 0 & 0 & $\mathbf{6}$ \\
\hline Total & $\mathbf{2 7 8}$ & $\mathbf{2 4 8}$ & $\mathbf{3 3 6}$ & $\mathbf{8 6 2}$ \\
\hline
\end{tabular}

\begin{tabular}{|l|c|c|c|c|c|}
\hline \multicolumn{1}{|c|}{ Age/Sex } & $\boldsymbol{P}$ & Male & Female & \multicolumn{2}{c|}{ Total } \\
\hline Infans I. & 78 & 0 & 0 & $\mathbf{7 8}$ & $\mathbf{( 9 , 1 \% )}$ \\
\hline Infans II. & 69 & 0 & 0 & $\mathbf{6 9}$ & $\mathbf{( 8 , 0 \% )}$ \\
\hline Juvenis & 41 & 9 & 15 & $\mathbf{6 5}$ & $\mathbf{( 7 , 5 \% )}$ \\
\hline Adultus & 38 & 112 & 166 & $\mathbf{3 1 6}$ & $\mathbf{( 3 6 , 7 \% )}$ \\
\hline Maturus & 37 & 126 & 154 & $\mathbf{3 1 7}$ & $\mathbf{( 3 6 , 8 \% )}$ \\
\hline Senilis & 0 & 1 & 1 & $\mathbf{2}$ & $\mathbf{( 0 , 2 \% )}$ \\
\hline Adultus-Senilis & 9 & 0 & 0 & $\mathbf{9}$ & $\mathbf{( 1 , 0 \% )}$ \\
\hline$?$ & 6 & 0 & 0 & $\mathbf{6}$ & $\mathbf{( 0 , 7 \% )}$ \\
\hline Total & $\mathbf{2 7 8 ( 3 2 , 2 \% )}$ & $\mathbf{2 4 8}(\mathbf{2 8 , 8} \%)$ & $\mathbf{3 3 6}(\mathbf{3 9 , 0 \% )}$ & $\mathbf{8 6 2}$ & \\
\hline
\end{tabular}

Fig. 4. Age and sex distribution of the buried individuals. Alsónyék-Bátaszék. 
The very low ratio of neonates in the cemeteries of the Lengyel (and other prehistoric) communities is usual, and the data from Alsónyék suggest no difference. However, in the case of other Lengyel samples, infant mortality is generally higher. The moderate number of children at the site of Alsónyék is a general phenomenon in other, later prehistoric series, which can be explained by the poor preservation of their small bones. Furthermore, child burials were perhaps placed in shallow graves, which were destroyed by erosion, agricultural work, etc.

Based on demographic observations of historical populations, a general trend can be assumed, showing higher mortality rates among adult aged individuals, and relatively lower mortality among mature-aged individuals. In contrast, series of the Lengyel culture display higher mortality rate among mature-aged individuals. The explanation of this phenomenon is still unclear (Fig. 5).

\begin{tabular}{|c|c|c|c|c|c|c|c|c|}
\hline Series/cultures & $?$ & $\begin{array}{c}\text { Inf. } \\
\text { I. }\end{array}$ & $\begin{array}{c}\text { Inf. } \\
\text { II. }\end{array}$ & Juv. & Ad. & Mat. & Sen. & Literature \\
\hline Alsónyék. Lengyel c. & 1.7 & 9.1 & 8.0 & 7.5 & 36.7 & 36.8 & 0.2 & Present thesis \\
\hline Bruchstedt, Central European LBK & - & 14.8 & 18.0 & 11.5 & 22.9 & 11.5 & 3.3 & ВАСН 1978. \\
\hline Sondershausen, Central European LBK & - & 10.6 & 14.9 & 6.4 & 40.5 & 25.5 & 2.1 & ВАСН 1978. \\
\hline Aszód-Papi földek, Lengyel c. & - & 21.0 & 18.2 & 5.0 & 24.3 & 27.6 & 3.9 & K. ZOFFMANN 2014. \\
\hline Zengővárkony, Lengyel c. & - & 4.7 & 1.6 & 5.5 & 24.5 & 48.9 & 14.8 & K. ZoFFMANN 1969-1970. \\
\hline Villánykövesd, Lengyel c. & - & 24.0 & 16.0 & 4.0 & 28.0 & 24.0 & 4.0 & K. ZOFFMANN 1968. \\
\hline Mórágy B.1., Lengyel c. & - & 21.9 & 19.5 & 11.0 & 11.0 & 25.6 & 11.0 & K. ZOFFMANN 2004. \\
\hline Mórágy B.2., Lengyel c. & - & 19.2 & 23.1 & 15.4 & 25.0 & 17.3 & - & K. ZOFFMANN 2013. \\
\hline Csabdi-Télizöldes, Lengyel c. & - & 8.8 & 23.5 & 8.8 & 32.4 & 26.5 & - & KÖHLER 2004. \\
\hline Szegvár-Tüzköves, Tisza c. & 4.8 & 15.8 & 4.8 & 9.5 & 28.6 & 27.0 & 9.5 & FARKAS ET AL. 1993; FARKAS 1994. \\
\hline Tápé-Széntéglaégető, Tisza c. & 25.2 & 7.9 & 15.4 & 5.7 & 29.9 & 13.5 & 2.4 & FARKAS - LIPTÁK 1971; 1975. \\
\hline Durankulak, Hamangia c. & 13.8 & 2.3 & 2.1 & 1.0 & 66.1 & 14.7 & - & YoRDANOV - Dimitrova 2002. \\
\hline Durankulak, Varna c. & 4.3 & 11.0 & 5.0 & 5.5 & 64.9 & 8.8 & 0.5 & YORDANOV - Dimitrova 2002. \\
\hline Khirokitia, Neolithic period & - & 34.1 & 3.3 & 0.8 & 50.0 & 11.8 & 0.0 & ANGEL 1953. \\
\hline Chamblandes c., Neolithic period & - & 15.4 & 3.8 & 26.9 & 15.4 & 30.9 & 7.6 & ACsÁdi - NEMESKÉRI 1970. \\
\hline La Barmaz, Neolithic period & - & 18.4 & 23.7 & 5.3 & 26.3 & 26.2 & - & MOESCHLER 1971. \\
\hline Vovnigi, Dnjepro-Donjec c. & - & \multicolumn{2}{|c|}{67.1} & 2.5 & 13.0 & 17.4 & 0.0 & KONDUKTOROVA 1973. \\
\hline Cernavoda, Hamangia c. & 14.9 & 2.3 & 2.9 & 2.9 & 11.7 & 63.7 & 2.5 & NeCRAsov ET AL. 1990. \\
\hline Cernica, Boian c. & 2.6 & 2.3 & 4.3 & 5.6 & 22.2 & 57.9 & 4.9 & NeCrasov et AL. 1990. \\
\hline
\end{tabular}

Fig. 5. Age and sex distribution of the buried individuals in other prehistoric cemeteries.

The ratio of male and female is not even in any known Lengyel cemetery; almost all of them are characterized by female dominance. The higher proportion of females may be attributed to flaws in the traditional sexing method, mortuary practices, polygamy, the death of males far from the community, etc. The demographic structure observed in the archaeologically outlined grave groups does not correlate with the assumed family relationship. Based on the low ratio of children, the unequal proportion of male and female burials, and the spatial distribution of child and adult burials next to each other, these groups do not seem to be representations of kinship-based organizations (Fig. 6). 


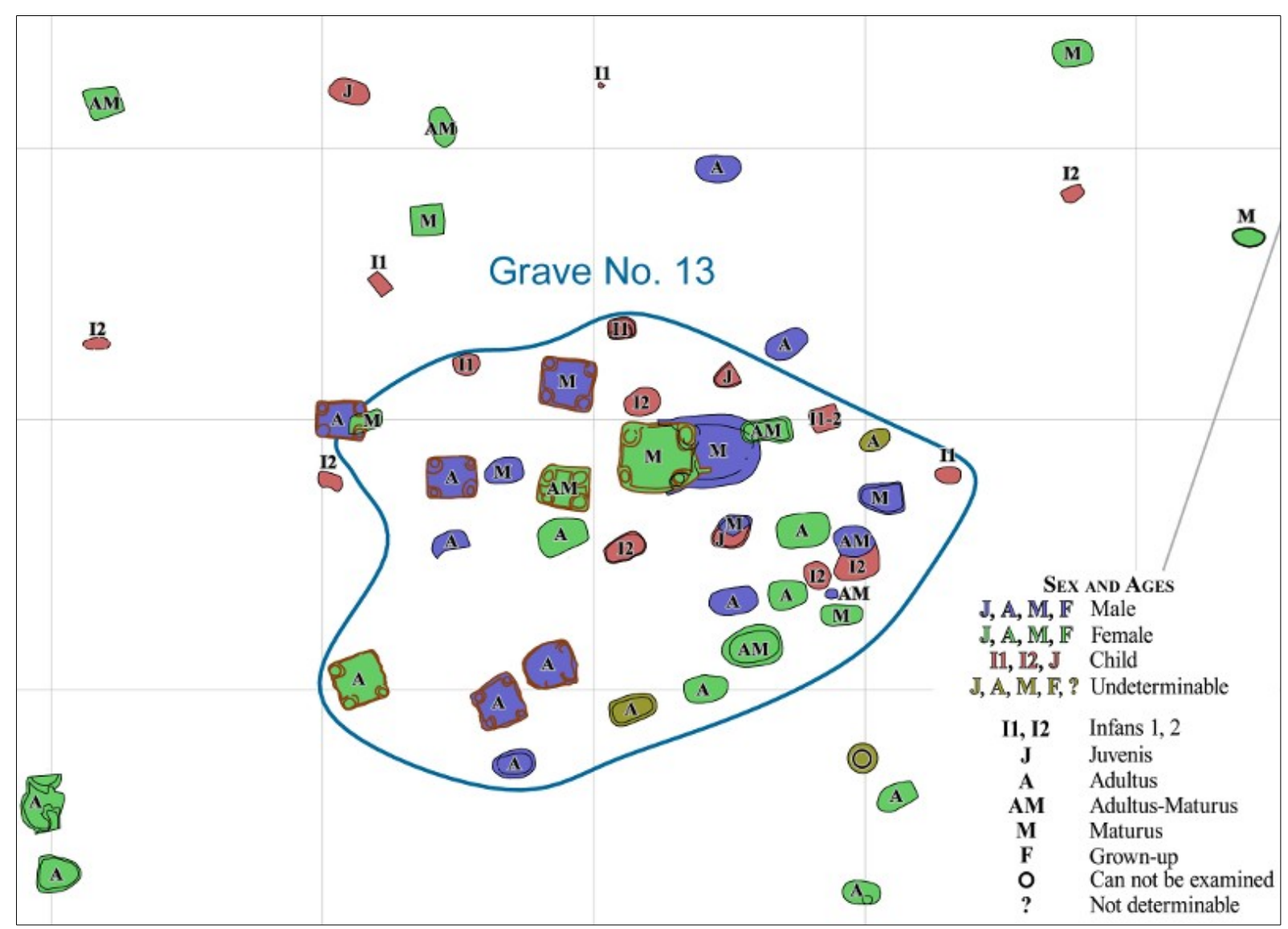

Fig. 6. Distribution according to sex and age in the case of burial group No. 13. (Zs. Réti - Á. Marton).

The analysis of anatomical variations on skeletal remains somewhat may modify the above described picture. In some cases, the manifestation of certain hereditary traits on the skulls of the individuals buried next to each other suggests affinity; however, the disproportionate demographic characteristics make it rather unlikely. Further verification of the kinship ties may become possible by the determination of the relative and absolute chronology of the burials, and by biomolecular analyses of the human remains. ${ }^{19}$

The morphometric analysis of the Alsónyék population presents a significant heterogeneity with the dominance of dolicho-, and hyperdolichocran-headed and leptoprosop-faced individuals. Due to the mosaic-like distribution of individual sizes and indices, their classification into concrete variants was not possible.

Results of the taxonomic analysis of the series from Alsónyék compared to earlier analyzed series from other Lengyel cemeteries produced some novel information on the anthropological composition of the culture..$^{20}$ It can be established that the previous assumption of the dominance of the Atlanto-Mediterranean and Nordoid types cannot be maintained any longer. Present analysis of the Alsónyék population suggests the dominance of the Gracile Mediterranean variant within the Lengyel population (Fig. 8). These results have fundamental effects on our understanding on the anthropological composition of the Lengyel population.

19 The DNA analysis was carried out in the Laboratory of Archaeogenetics of the Research Center for the Humanities, HAS, Archaeological Institute. Although the first analysis was unsuccessful, it will be repeated in the future.

20 NeMESKÉRI 1961; SZATHMÁry 1981; K. ZOFFMANN 1968; 1969-1970; 2001. 
In order to answer questions concerning the origin of the human populations of the Lengyel culture, I conducted a comparative craniometric analysis incorporating Penrose, Euclidean and Chebyshev distance measurements and Pearson's correlation matrix. Based on the series of 38 males and 26 females sampled from Carpathian Basin, North-, East-, Central-, South-, and Southeast-European, and Near Eastern Neolithic and Copper Age populations, the series of Alsónyék represents significant relations with only a few (Fig. 7). In the case of females, within a low significance level $(0.1 \%$ and $0.5 \%)$ all calculating methods show significant connections with the Lengyel series from the cemetery of Mórágy, the LBK series from the Bruchstedt cemetery in Germany, and the pooled LBK series from Bohemia. In the case of males, using the Penrose and Euclidean distance, there are no significant similarities with any series, not even at a generous, $1 \%$ significance rate. On the other hand, employing Chebyshev distance and Pearson's correlation matrix, the male sample presents many connections that cannot be explained on the basis of archaeological and anthropological literature. In total, the comparative craniometric analysis of the Alsónyék series reinforces Zoffmann's earlier Penrose results, which suggested an indigenous (LBK) biological origin for the population of the culture. ${ }^{21}$

\begin{tabular}{|c|c|c|c|c|c|c|c|c|}
\hline \multirow[b]{2}{*}{ Series } & \multicolumn{2}{|c|}{ Penrose } & \multicolumn{2}{|c|}{ Euclidean } & \multicolumn{2}{|c|}{ Chebyshev } & \multicolumn{2}{|c|}{ Pearson } \\
\hline & $\sigma^{*}$ & 우 & $0^{*}$ & 우 & $\sigma^{*}$ & 운 & $\sigma^{*}$ & 우 \\
\hline Lengyel c., Aszód-Papi földek & 0.361 & 0.149 & 1.881 & 1.485 & 1.5 & 0.947 & 0.995 & 0.998 \\
\hline Lengyel c., Mórágy B.1 & 0.566 & 0.136 & 2.802 & 1.191 & 1.98 & $\underline{0.667}$ & 0.992 & 0.998 \\
\hline Lengyel c., South Transdanubia & 0.388 & 0.169 & 2.04 & 1.391 & 1.275 & $\underline{0.646}$ & 0.994 & 0.998 \\
\hline Lengyeli c., Lower Austria & - & 0.388 & - & 1.97 & - & 1.118 & - & 0.996 \\
\hline Starčevo c. & 0.675 & 0.309 & 2.766 & 1.89 & 2.367 & 0.979 & 0.989 & 0.996 \\
\hline Körös c. & - & 1.023 & - & 3.65 & - & 1.789 & - & 0.988 \\
\hline Early LBK + Bükk c. & 1.097 & - & 1.744 & - & 2.137 & - & 0.987 & - \\
\hline Central European LBK, Transdanubia & 0.257 & 0.253 & 3.822 & 1.594 & 1.167 & 0.958 & 0.996 & 0.997 \\
\hline Vinča c., Hrtkovci-Gomolava & 0.317 & - & 1.833 & - & 0.944 & - & 0.996 & - \\
\hline Tisza c. & 0.501 & 0.227 & 2.248 & 1.529 & 1.556 & 1.176 & 0.994 & 0.997 \\
\hline Tiszapolgár c. & 0.426 & - & 2.118 & - & 1.163 & - & 0.996 & - \\
\hline Bodrogkeresztúr c. & 0.24 & - & 1.581 & - & 1.061 & - & 0.998 & - \\
\hline Baden c.. Budakalász & 0.457 & - & 2.164 & - & 1.26 & - & 0.993 & - \\
\hline Baden c., Budapest Region & 0.507 & 0.251 & 2.285 & 2.221 & 1.36 & 1.259 & 0.992 & 0.998 \\
\hline Baden c., Balaton Region & 0.484 & 0.703 & 2.223 & 2.657 & 1.167 & 2 & 0.993 & 0.991 \\
\hline Central European LBK, Germany & 0.257 & - & 2.244 & - & 1.526 & - & 0.997 & - \\
\hline Central European LBK, Bohemia & 0.432 & 0.155 & 2.283 & 1.271 & 1.176 & 0.765 & 0.994 & 0.998 \\
\hline Central European LBK, Bruchstedt & - & $\underline{0.06}$ & - & 0.891 & - & 0.535 & - & 0.999 \\
\hline Central European LBK, Sondershausen & 0.333 & 0.238 & 2.501 & 1.594 & 1.722 & 0.941 & 0.997 & 0.996 \\
\hline Corded Ware c., Bohemia & 0.332 & - & 1.926 & - & 1 & - & 0.995 & - \\
\hline Corded Ware c., Poland & 0.958 & 0.289 & 3.436 & 1.708 & 2.278 & 1.118 & 0.987 & 0.996 \\
\hline Corded Ware c., Germany & 0.32 & 0.471 & 1.912 & 2.217 & 1.5 & 1.706 & 0.996 & 0.993 \\
\hline
\end{tabular}




\begin{tabular}{|c|c|c|c|c|c|c|c|c|}
\hline \multirow[b]{2}{*}{ Series } & \multicolumn{2}{|c|}{ Penrose } & \multicolumn{2}{|c|}{ Euclidean } & \multicolumn{2}{|c|}{ Chebyshev } & \multicolumn{2}{|c|}{ Pearson } \\
\hline & $\hat{o}$ & 운 & $\sigma^{2}$ & 우 & $\sigma^{2}$ & 우 & $\sigma^{\pi}$ & ㅇ \\
\hline Złota c., Poland & 1.01 & 0.718 & 3.183 & 2.71 & 2 & 1.447 & 0.986 & 0.989 \\
\hline Jordanovc., Brzesc Kujawski & 0.662 & - & 2.577 & - & 1.395 & - & 0.99 & - \\
\hline Waltern.-Bernb. c., Schönstedt & 0.243 & 0.47 & 1.599 & 2.495 & 0.944 & 1.647 & 0.997 & 0.994 \\
\hline Fatjanovo c., Russia & 1.009 & 0.907 & 3.372 & 3.151 & 2.389 & 2.353 & 0.985 & 0.986 \\
\hline Tripolje c., Ukraina & 0.658 & 0.817 & 2.557 & 2.859 & 1.667 & 2.235 & 0.992 & 0.988 \\
\hline Tripolje c., Bilcze Zlote & 0.46 & - & 2.124 & - & 1.222 & - & 0.995 & - \\
\hline Dnjepro-Donjec c., Vovnigi & 1.738 & - & 5.691 & - & - & - & 0.982 & - \\
\hline Dnjepro-Donjec c., Volnoje & 2.114 & 1.549 & 6.715 & 6.003 & 4.056 & 3.521 & 0.982 & 0.987 \\
\hline Dnjepro-Donjec c., Dereivka & 1.428 & - & 5.415 & - & 3.294 & - & 0.987 & - \\
\hline Dnjepro-Donjec c., Nikolskoje & 2.001 & - & 6.042 & - & - & - & 0.979 & - \\
\hline Dnjepro-Donjec c., Ukraina+Russia & 1.756 & 1.296 & 5.781 & 4.835 & 3.627 & 3.229 & 0.982 & 0.986 \\
\hline Lepenski Vir c., Serbia & 0.968 & 1.213 & 4.222 & 4.845 & 2.765 & 3.104 & 0.989 & 0.989 \\
\hline Boian c., Cernica & 0.336 & 0.401 & 1.82 & 2.361 & 1 & 1.294 & 0.997 & 0.996 \\
\hline Gumelniţa c., Ruse & 0.563 & 0.489 & 2.372 & 2.268 & 1.944 & 1.138 & 0.992 & 0.993 \\
\hline Nea Nikomedeia, Neolithic & - & 0.347 & - & 2.05 & - & 1.588 & - & 0.996 \\
\hline Al'Ubaid, Neolithic & 0.812 & - & 3.226 & - & 1.833 & - & 0.991 & - \\
\hline Troy I-V,. Neolithic & 2.401 & - & 5.372 & - & 4.517 & - & 0.968 & - \\
\hline Greek, Neolithic+Early Helladic & 0.485 & - & 2.254 & - & 1.469 & - & 0.994 & - \\
\hline Central and Eastern Anatolia, Chalcolithic & 0.475 & - & 2.302 & - & 1.51 & - & 0.993 & - \\
\hline Tepe Hissar II., Chalcolithic & 0.662 & 0.36 & 2.576 & 2.046 & 1.653 & 1.383 & 0.993 & 0.996 \\
\hline
\end{tabular}

Fig. 7. The results of the craniometric analysis incorporating Penrose, Euclidean and Chebyshev distance measurements and Pearson's correlation matrix. The bolded and underlined data signed the stronger, $0.1 \%$ significance level, while the only bolded numbers signed the looser ( $0.5 \%$ significance level) relationship.

Anthropological differences and similarities between populations of the Eastern and Western Carpathian Basin during this time period have been long debated. While Szathmáry partially originates the Late Neolithic population of the Tisza culture from the south, ${ }^{22}$ Zoffmann dismisses this possibility. ${ }^{23}$ According to Zoffmann's opinion, the populations of the Tisza and Lengyel cultures were in close genetic relations with each other. This may suggest small-scale or more significant population shifts within the Carpathian Basin during the Late Neolithic. Using the Penrose and Euclidean distance calculations, the female series from Alsónyék, does not represent significant similarities with the population of the Tisza culture. However, significant connections occurred between these populations at the significance level of $0.5 \%$, using the Chebyshev distance and Pearson correlation matrix. Meanwhile, there is absolutely no observable correlation between the male series from Alsónyék and the population of the Tisza culture irrespectively of the distance measuring methodology. We have to admit, however, that beyond a narrow significance level (!), the population of the Tisza culture provides the closest relation to the population of the Alsónyék cemetery. 
The detailed paleopathological analysis of the skeletal population of the cemetery shows a relatively low ratio of traumatic deformations, non-specific inflammations, and degenerative articular diseases (Fig. 9-10). As for the hematological disorders, cribra orbitale occurred with a high incidence among children, which likely reflects iron deficient diet (Fig. 11). At the same time, among adults the most frequent alterations were enthesopathic deformities, primarily on the calcaneum, which are generally considered to be markers of a rather active lifestyle (Fig. 12). Beside these above-mentioned alterations some rare or significant diseases occurred, too. These include cases of benign tumor and of so-called pathological birth. Two cases of deformities affecting the frontal ligaments of the spinal column suggesting DISHsyndrome.

Beside these the most important pathological alteration occurred in the case of an individual buried in a post-framed grave construction (Grave No. 4027). On the spinal column of this person the very typical morphological lesions (collapse and fusion of vertebral bodies) caused by tuberculosis could be observed (Fig. 13). Further on, apart from this person showing classic symptoms of the disease, we decided to examine the presence of the so-called atypical syndrome on all of the skeletal finds excavated in this group (No. 13) of graves, in cooperation with the Department of Anthropology of the University of Szeged. Beside this, we were also going to investigate whether the DNA remnants of the pathogen can be detected from the bones. ${ }^{24}$ The significance of these results are that beside the presence of the disease on the Great Hugarian Plain during the Neolithic Period (HódmezóvásárhelyGorzsa, Vésztő-Mágor $)^{25}$ this is the first recognizable TB infection in Transdanubia.

The oral pathological examinations revealed a general low frequency of carious lesions, alveolar abscesses and cysts, which suggests an adequate dental hygiene. However, the frequent appearance of dental hypoplasia suggests unpredictable food supply in the early childhood.

I had the opportunity to analyze 68 individuals who were buried in post-framed grave constructions. The demographic and morphometric characteristics of them show overall similarities to the rest of the population of the Alsónyék community. The frequency of different pathological alterations and dental diseases is also similar to that of the rest of the population buried in simple graves. Based on these, the archaeologically manifested socio-economic differentiation cannot be supported by the physical anthropological characteristics and by the lifestyle among the members of the Alsónyék community.

The verification of the above outlined results and interpretations, as well as the clarification of unanswered questions will be possible only through the physical anthropological analysis of the full population of the Alsónyék cemetery. Proceedings in the physical anthropological investigations considering the Lengyel culture require further burial excavations, which may give us a better understanding on the Early- and Middle Neolithic of the region and of the other contemporary, Late Neolithic populations of Western Transdanubia.

24 The ongoing DNA research is realized in the framework of the OTKA K 81230 project at the EURAC Institute for Mummies and the Iceman in Bolzano. The relatively good state of preservation of the material, the important chronological period of the series and the presence of classical TB symptoms encouraged us to carry out a DNA test of TB-related lesions in grave group No. 13. According to its preliminary results, further TB--infected individuals occurred in the group (KöHLER ET AL. 2013; PósA ET AL. 2013).

25 MASSON 2011; SPEKKER ET AL. 2012. 


\section{References}

AcsÁDI, Gy. - NEMESKÉRI, J. 1970: History of human life span and mortality. Budapest.

Alekseiev, V. P. - Debets, G. F. 1964: Kraniometrija. Moszkva.

Angel, J. L. 1953: The human remains from Khirokitia. In: Dikaios, P. (ed.), Khirokitia. Final report on the excavation of a Neolithic settlement in Cyprus on behalf of the Department of Antiquities 1936-1946. Oxford, 416-430.

BAch, A. 1978: Neolitische Populationen im Mittelelbe-Saale-Gebiet. Zur Anthropologie des Neolitikums unter besonderer Berücksichtigung der Bandkeramiker. Weimarer Monographien zur Ur- und Frühgeschichte 1. Weimar.

BERNERT, Zs. 2005: Kárpát-medencei történeti népességek végtagarányai és testmagassága. In: KoRsós, Z. (ed.), IV. Kárpát-medencei Biológiai Szimpózium. Elóadások összefoglalói. Budapest, 35-43.

Bernert, Zs. - Csapó, J. - Eszterhás, I. 2002: Analysis of the anthropological material of Balatonederics Döme Cave. Annales historico-naturales Musei nationalis hungarici 94, 227-235.

Bernert, Zs. - Évinger, S. - HAJdu, T. 2007: New data on the biological age estimation of children using bone measurements based on historical populations from the Carpathian Basin. Annales historico-naturales Musei Nationalis hungarici 99, 199-206.

Ehgartner, W. 1956: Ein lengyelzeitlicher "Glockenbecherschädel" aus Eggenburg, NÖ. Mitteilungen der Anthropologischen Gesellschaft in Wien 86, 58-63.

Ehgartner, W. - Jungwirth, J. 1956: Ein lengyelzeitliches Schädelnest aus Poigen, NÖ. Archaeologica Austriaca 19-20, 77-89.

Éry, K. - Kralovánszky, A. - Nemeskéry, J. 1963: Történeti népességek rekonstrukciójának reprezentációja (A representative reconstruction of historic population.) Anthropologiai Közlemények 7, 41-90.

FARKAS, Gy. - LiptÁk, P. 1971: A Tápé mellett feltárt késő bronzkori temető antropológiai értékelése (Die anthropologische Auswertung des spätbronzezeitlichen Gräberfeldes bei Tápé). Anthropologiai Közlemények 15, 3-18.

FARKAS, Gy. - LiptÁK, P. 1975: Anthropologische Auswertung des bronzezeitlichen Gräberfeldes bei Tápé. In: Trogmayer, O. (ed.), Das bronzezeitliche Gräberfeld bei Tápé. Fontes Archaeologici Hungariae 17. Budapest, 229-267.

FARKAS, Gy. 1994: Szegvár-Tüzköves neolitikus csontleleteiről. In: Lőrinczy, G. (ed.), A kókortól a középkorig. Tanulmányok Trogmayer Ottó 60. születésnapjára (Von der Steinzeit bis zum Mittelalter. Studien zum 60. Geburstag von Ottó Trogmayer). Szeged, 143-150.

Farkas, Gy. - Marcsik, A. - OláH, S. 1993: Történeti idők embere Szegváron. Anthropologiai Közlemények 35, 7-37.

Ferembach, D. - Schwiedetzky, I. - Stloukal, M. 1979: Empfehlungen für die Alters- und Geschlechtsdiagnose am Skelett. Homo 30, 1-32.

Finnegan, M. 1972: Population definition on the northwest coast by analysis of discrete character variation. Ph.D. Diss., University of Colorado, Boulder.

Gallina, Zs. - Hornok, P. - Paluch, T. - Somogyi, K. 2010: Előzetes jelentés az M6 AP TO 10/B és 11. számú lelőhelyrészen végzett megelőző feltárásról. Alsónyék-Bátaszék (Tolna megye) 2006-2009. A Wosinsky Mór Múzeum Évkönyve 32, 7-100. 
Hauser, G. - De Stefano, G. F. 1989: Epigenetic variants of the human skull. Stuttgart.

IşCAN, M. Y. - Loth, S. R. - Wright, R. K. 1985: Age estimation from the rib by phase analysis: White Females. Fournal of Forensic Sciences 30, 853-863.

JАКАВ, J. 1986: Anthropologie der Skelette der träger der Lengyelkultur in Svodín. In: Internationales Symposium über die Lengyel-Kultur. Nové Vozokany 5.9. November 1984. Nitra - Wien, 89-94.

Jungwirth, J. 1956: Ein neolithischer Schädel aus Bisamberg bei Wien. Mitteilungen der Anthropologischen Gesellschaft in Wien 86, 71-74.

Jungwirth, J. 1967: Zwei lengyelzeitliche Schädel aus Poysdorf, Niederösterreich. Mitteilungen der Anthropologischen Gesellschaft in Wien 96-97, 57-63.

Jungwirth, J. 1973: Ein lengyelzeitliches Skelett aus Wetzleinsdorf, Niederösterreich. Mitteilungen der Anthropologischen Gesellschaft in Wien 103, 19-27.

KAlicz, N. 1988: A termelőgazdálkodás kezdetei a Dunántúlon. Akadémiai Doktori Értekezés. Budapest.

Kalicz, N. 2001: Der Neuere Forschungsstand über die Lengyel Kultur. In: RegenYe, J. (ed.), Sites and stones: Lengyel culture in Western Hungary and beyond. A reiew of the current research. Lengyel'99 and IGCP-442 Conference. Veszprém, 7-13.

Kiszely, I. 1973: Untersuchung der Menschenknochen aus der urzeitlichen Siedlung und dem Gräberfeld von Altacker in Pári. Mitteilungen der Archäologischen Instituts der Ungarischen Akademie der Wissenschaften 4, 119-128.

Konduktorova, T. S. 1973: Anthropologija naselenija Ukrainy mezolita, neolita i epochi bronzy (Physical anthropology of the Ukrainian population in the Mesolithic, Neolithic, and Bronze Age). Moszkva.

KöHLER, K. 2003: A Lengyeli kultúra embertani leletei Karancsság lelőhelyről. - Anthropological finds of the Lengyel culture from Karancsság. Ösrégészeti Levelek/Prehistoric Newsletter 5, $33-37$.

KöHLER, K. 2004: Anthropological finds of the Lengyel culture from Csabdi-Télizöldes. Alba Regia 33, $7-24$.

KöHLER, K. 2006: A Lengyeli és a Balaton-Lasinja kultúra embertani leletei Veszprémből (Anthropological Finds of the Lengyel and Balaton-Lasinja culture from Veszprém). Veszprém Megyei Múzeumi Közlemények 24, 37-48.

Köhler, K. - PÁlfi, Gy. - Molnár, E. - Zalai-GaÁl, I. - Osztás, A. - BÁnffy, E. - Kirinó, K. Kiss, K. K. - Mende, B. G. 2013: A Late Neolithic case of Pott's disease from Hungary. International fournal of Osteoarchaeology. DOI: 10.1002/oa.2254.

KöHler, K. - Mende, B. G. - PósA, A. 2013: The Emergence of Tuberculosis in late neolithic Transdanubia. Hungarian Archaeology 2013 Summer (http://www.hungarianarchaeology.hu/wpcontent/uploads/2013/08/eng_Kohler_13ny1.pdf).

KővÁRI, I. 2008: Az Alföld őskori népességeinek megitélése kraniometriai elemzésük révén. $\mathrm{PhD}$ diszszertáció. Debreceni Egyetem, Debrecen.

KővÁRI, I. - SzathmÁry, L. 2001: Népességek továbbélése az őskorban. In: Isépy, I. - Korsós, Z. PAP, I. (eds.), II. Kárpát-medencei Biológiai Szimpózium. Elóadások összefoglalói. Budapest, 299-302.

LiptÁk, P. 1962: Homo sapiens - species collectiva. Anthropologiai Közlemények 6, 17-27. 
LiptÁk, P. 1965: On the Taxonomic Method in Palaeoanthropology (Historical Anthropology). Acta Biologica Szegediensis 11, 169-183.

MALÁN M. 1929: Adatok a Lengyeli őstelep neolithkori lakóinak anthropológiájához. Budapest.

MARTin, R. - SALLER, K. 1957: Lehrbuch der Anthropologie I-II. Stuttgart.

Masson, M. 2011: Tuberculosis at the Late Neolithic site of Hódmezővásárhely-Gorzsa, Hungary. 13th Annual Conference of the British Association for Biological Anthropology and Osteoarchaeology. Programme and Abstracts, 27-28.

MeindL, R. S. - Lovejoy, C. O. 1985: Ectocranial suture closure: A revised method for the determination of skeletal age at death based on the lateral-anterior sutures. American fournal of Physical Anthropology 67, 51-63.

Miles, A. E. W. 1963: The dentition in the assesment of individual age in skeletal material. Human Biology 5, 191-209.

Moeschler, P. 1971: Les cimetrières néolithiques de Chamblandes (Pully, Vaud), Barmaz I et Barmaz II (Collombey, Valais). Approche démographique. Archives suisess d'Anthropologie générale 34, 76-78.

Necrasov, O. - Cristescu, M. - Botezatu, D. - Miv, G. 1990: Cercetări paleoantropologice privitoare la populaţiile de pe teritoriul României (Recherces paléoanthropologiques concernant les populations qui vécurent sur le territorie de la Roumanie). Arheologia Moldovei 13, 173-224.

Nemeskéri, J. 1955: A Természettudományi Múzeum Embertani Tára történeti embertani gyűjteményének gyarapodása az 1950-1954. években. Annales historico-naturales Musei Nationalis hungarici 6, 411-415.

NeMESKÉRI, J. 1961: Die wichtigsten anthropolgischen Fragen der Urgeschichte in Ungarn. Anthropologiai Közlemények 5, 39-47.

Nemeskéri, J. - Harsányi, L. - Acsádi, Gy. 1960: Methoden zur Diagnose des Lebensalters von Skelettfunden. Anthropologischer Anzeiger 24, 70-95.

Neugebauer-Maresch, Ch. - Teschler-Nicola, M. 2006: Zu den perimortalen Beschädigungen und postmortalen Lageveränderungen der Bestattungen von Friebritz (NÖ.) und ihre Bedeutung für die mittelneolithische Kreisgrabenanlage. In: Krenn-Leeb, A. - Grömer, K. - Stadler, P. (Hrsg.), Ein Lächeln für die fungsteinzeit. Ausgewählte Beiträge zum Neolithikum Ostösterreichs. Festschrift für Elizabeth Ruttkay. Archäologie Österreichs 17.2. Wien, 31-40.

PAP, I. 2012: Antropológia és régészet. Egy változó viszony? (Anthropology and archaeology. A changing relationship?). In: Kreiter, A. - Pető, Á. - Tugya, B. (eds.), Környezet-EmberKultúra. A természettudományok és a régészet párbeszéde (Environment-Human-Culture. Dialogue between applied sciences and archaeology.) MNM-NÖK 2010. október 6-8-án megrendezett konferenciájának tanulmánykötete. Budapest, 233-240.

Penrose, L. S. 1954: Distance, size and shape. Annals of Eugenics 18, 337-343.

Pósa, A. - Mende, B. G. - Köhler, K. - Maixner, F. - Zink, A. - Molnár, E. - Bereczki, Z. - PerRIN, P. - SolA, C. - PÁlfi, G. 2013: Late Neolithic human samples used for TB paleomicrobial research. German Society of Anthropology (GfA) September 2nd - 6th 2013, EURAC Research Bolzano/Bozen, Italy. Program and abstracts, 35.

Rahmann, N. A. 1962: On the sampling distribution of the studentized Penrose measure of distance. Annals of Human Genetics 26(2), 97-106. 
RösIng, F. W. 1988: Körperhöhenrekonstruktion aus Skelettmassen. In: KnussmanN, R. (Hrsg.), Anthropologie. Handbuch der vergleichenden Biologie des Menschen. Band I. Stuttgart - New York, $586-600$.

Ruttkay, E. - Teschler-Nicola, M. 1985: Zwei Lengyel Gräber aus Niederösterreich. Annalen des Naturhistorisches Museums in Wien 87, 211-235.

SAUNDERS, S. R. 1978: The development and distribution of discontinuous morphological varation of the human infracranial skeleton. National Musem of Man, Mercury Series 81. Ottawa.

Schinz, H. - Baensch, W. - Friedl, E. - Uehlinger, E. 2012: Ossifikationstabelle. In: Lehrbuch der Röntgen-Diagnostik. (5. Aufl.). Stuttgart.

Schour, J. - Massler, M. 1941: The development of the human dentition. The fournal of American Dental Association 28, 1153-1160.

SchÜrer von Waldheim, H. 1919: Vorgeschichtliche menschliche Funde aus Stillfried. Mitteilungen der Anthropologischen Gesellschaft in Wien 47-49, 247-263.

SJøvold, T. 1990: Estimation of stature from long bones utilizing the line of organic correlation. $\mathrm{Hu}$ man Evolution 5, 431-447.

Spekker, O. - PÁlfi, Gy. - Kozocsay, G. - Pósa, A. - Bereczki, Zs. - Molnár, E. 2012: New cases of probable skeletal tuberculosis from the Neolithic period in Hungary - A morphological study. Acta Biologica Szegediensis 56(2), 115-123.

SteInbock, R. T. 1976: Paleopathological diagnosis and interpretation. Springfield, Illinois.

Stloukal, M. - HanÁkovÁ, H. 1978: Die Länge der Längsknocken altslawischer Bevölkerungen unter besonderer Berücksichtigung von Wachstumsfragen. Homo 29, 53-69.

Strouhal, E. - Jungwirth, J. 1970: Die menschlichen Skelette aus dem neolithischen Hornsteinbergwerk von Mauer bei Wien. Mitteilungen der Anthropologischen Gesellschaft in Wien 50, $85-110$.

Szathmáry, L. 1980: Autochtons and immigrated components in the Carpathian Basin Copper Age. The Fournal of Indo-European Studies 8, 231-244.

Szathmáry, L. 1981: The Skeletal History of the Neolithic in the Carpathian Basin. A Debreceni Déri Múzeum Évkönyve, 51-66.

SzILvÁssy, J. 1978: Eine Methode zur Altersbestimmung mit Hilfe der sternalen Gelenksflächen der Schlüsselbeine. Mitteilungen der Anthropologischen Gesellschaft in Wien 108, 166-168.

Tóтн, G. 1996-1997: Az Ö. 92. 123. leltári számú emberi csontmaradvány a séi neolit telepről. Savaria 23.3, 19-21.

TóтH, G. 2002: Újabb embertani adat Vas megye őskorához. Savaria 27, 215-218.

То́тн, G. 2009: Embertani adatok Zala megye őskorához (Anthropologische Daten zu der Urzeit des Regierungsbezirks Zala.) In: ILoN, G. (ed.), Nyersanyagok és kereskedelem (Raw materials and Trade). $M \Omega M O \Sigma$ 6. Szombathely, 427-430.

Tóтн, G. 2011: Jelentés a Nagykanizsa-Palin, Agyagnyerő lelőhely emberi csontanyagának vizsgálatáról (Lengyel-kultúra). Folia Anhtropologica 10, 107-108.

TodD, T. W. 1920: Age changes in the pubis bone: I. The male white pubis. American fournal of Physical Antropology 3, 285-334.

Ubelaker, D. H. 1989: Human Skeletal Remains. Excavation, Analysis, Interpretation. Washington. 
VIRCHOW, R. 1890: Excursion nach Lengyel (Südungarn). Verhandlungen der Berliner anthropologischen Gesellschaft, 97-118.

VLČEK, E. 1961: Antropologický materiál z neolitických hrobu v Lužiankách (Anthropological material from the Neolithic graves at Lužianky). Musaica 12, 69-80.

VLČEK, E. - BARTA, J. 1950: Lengyelský kostrovy hrob z Malých Krštenan /okr. Partizánske/ (Tombeau á squelette de Malé Krštenany prés de Partizánské, Slovaquie). Obzor Prehistorický 14, 337-340.

ZALAI-GAÁL, I. - OszTÁs, A. 2009: A Lengyeli kultúra települése és temetője Alsónyék-Kanizsadűlőben (A settlement and cemetery of the Lengyel culture at Alsónyék-Kanizsa-dűlő). In: Bende, L. - LőRInczy, G. (eds.), Medinától Etéig. Szentes, 245-254.

ZimmermanN, G. 1935: Jungsteinzeitliche Schädelfunde aus Langenlois und deren Beziehungen zur Pfahlbaurasse. Archiv der Fulius Klaus Stiftung 10, 227-236.

K. Zoffmann, Zs. 1968: An anthropological study of the Neolithic cemetery at Villánykövesd (Lengyel Culture). A Janus Pannonius Múzeum Évkönyve 13, 25-37.

K. Zoffmann, Zs. 1969-70: Anthropological analysis of the cemetery at Zengővárkony and the Neolithic Lengyel Culture in SW Hungary. A Janus Pannonius Múzeum Évkönyve 14-15, 53-72.

K. Zoffmann, Zs. 1992: Kelet Kárpát-medence neolitikus és rézkori népességeinek embertani vázlata. Kandidátusi disszertáció. Budapest.

K. Zoffmann, Zs. 1998-1999: Anthropological data of the Transdanubian Prehistoric populations living in the Neolithic, the Copper, the Bronze and the Iron Ages. Savaria 24.3, 33-49.

K. Zoffmann, Zs. 2001: Anhropological Structure of the Prehistoric populations living in the Carpathian Basin in the Neolithic, Copper, Bronze and Iron age. Acta Archaeologica Academiae Scientiarium Hungaricae 52, 49-62.

K. Zoffmann, Zs. 2004: A Lengyeli kultúra Mórágy B.1. temetkezési csoportjának embertani ismertetése (Anthropologische Funde des neolithischen Gräberfeldes Mórágy B.1 aus der Lengyel-Kultur). A Wosinszky Mór Megyei Múzeum Évkönyve 26, 137-179.

K. Zoffmann, Zs. 2007: Anthropological material from a Neolithic common grave found at Esztergályhorváti (Lengyel Culture, Hungary). Folia Anthropologica 6, 53-60.

K. Zoffmann, Zs. 2011: Somogy megyei régészeti ásatásokon elszórtan előkerült őskori embertani leletek. (Adatközlés) (Sporadically found prehistoric anthropological finds from Somogy County.) Folia Anthropologica 10, 65-76.

K. Zoffmann, Zs. 2014: Anthropological investigation of the cemetery dated to the Lengyel culture unearthed at Aszód-Papiföldek. In: Kalicz, N., SikLósi, Zs., Kovács, K. (eds.), Aszód-Papi földek késő neolitikus lelóhely: kapcsolat kelet és nyugat között (The Late Neolithic site of AszódPapi földek: connection between east and west). Budapest, in press.

K. Zoffmann, Zs. 2013: Embertani leletek a Lengyeli kultúra Mórágy-Tűzkődomb B.2 lelőhelyen részlegesen feltárt sírcsoportjából. Folia Anthropologica, in press.

YordANOv, Y. - DimitriovA, B. 2002: Results of an anthropological study of human skeletal remains of the prehistoric necropolis in the vicinity of the village of Durankulak. In: Todorova, $\mathrm{H}$. (ed.), Durankulak, Band II. Die Prähistorischen Gräberfelder. Teil 1. Sofia, 325-347. 


\section{The author's published papers on the topic of the PhD dissertation}

Hajdu, T. - Fóthi, E. - Bernert, Zs. - MolnÁr, E. - LovÁsz, G. - KővÁri, I. - KöHler, K. - Marcsik, A. 2009: Appearance of hyperostosis frontalis interna in some osteoarchaeological series from Hungary. Homo - Journal of Comparative Human Biology 60, 185-205.

Köhler, K. - PÁlfi, Gy. - Molnár, E. - Zalai-GaÁl, I. - Osztás, A. - BÁnffy, E. - Kirinó, K. Kiss, K. K. - Mende, B. G. 2012: A Late Neolithic case of Pott's disease from Hungary. International fournal of Osteoarchaeology, DOI: 10.1002/oa.2254.

Köhler, K. - Zalai-GaÁl, I. - Osztás, A. - BÁnffy, E. - Kirinó, K. - Kiss, K. K. - PÁlfi, Gy. Mende, B. G. 2012: Skeletal tuberculosis in a Late Neolithic serie from Hungary. 75th Anniversary of Albert Szentgyörgyi's Nobel Prize Award. Szeged, 22-25 March, 2012. ICEPT 2 -Tuberculosis Evolution Meeting, Final Programme, 317.

KöHLER, K. 2003: A Lengyeli kultúra embertani leletei Karancsság lelőhelyről. Ösrégészeti Levelek 5, 33-37.

KöHLER, K. 2004: Anthropological finds of the Lengyel culture from Csabdi-Télizöldes. Alba Regia 33, $7-24$.

KöHLER, K. 2006: A Lengyeli és a Balaton-Lasinja kultúra embertani leletei Veszprémből (Anthropological finds of the Lengyel and Balaton-Lasinja culture from Veszprém). Veszprém Megyei Múzeumi Közlemények 24, 37-48.

KöHLER, K. 2013: Ergebnisse der anthropologischen Untersuchungen zweier spätneolithischer Bestattungen in Alsónyék. In: Anders, A. - Kulcsár, G. (eds.), Moments in Time. Papers Presented to Pál Raczky on His 60th Birthday. Ösrégészeti Tanulmányok/Prehistoric Studies 1. Budapest, 401-405.

Zalai-GaÁl, I. - GÁl, E. - KöHler, K. - Osztás, A. - Szilágyi, K. 2012: Präliminarien zur Sozialarchäologie des lengyelzeitlichen Gräberfeldes von Alsónyék-Bátaszék, Südtransdanubien. Praehistorische Zeitschrift 87(1) 58-82.

Zalai-GaÁl, I. - Gál, E. - KöHleR, K. - Osztás, A. 2009: Eberhauerschmuck und SchweinekieferBeigaben in den Neolithischen und kupferzeitlichen Bestattungssitten des Karpatenbeckens. Acta Archaeologica Academiae Scientiarum Hungaricae 60, 303-355.

ZAlAI-GAÁl, I. - GÁL, E. - KöHLER, K. - OszTÁs, A. 2011: „Ins Jenseits begleitend“: Hundemitbestattungen der Lengyel-Kultur von Alsónyék-Bátaszék. Acta Archaeologica Academiae Scientiarum Hungaricae 62, 29-74.

Zalai-GaÁl, I. - GÁL, E. - KöHler, K. - OsztÁs, A. 2011: Das Steingerätedepot aus dem Häuptlingsgrab 3060 der Lengyel-Kultur von Alsónyék, Südtransdanubien. In: Beiträge zur Ur- und Frühgeschichte Mitteleuropas 63. Varia Neolithica 7, 65-83.

Zalai-GaÁl, I. - Köhler, K. - OsztÁs, A. 2010: Zur Typologie und Stellung von Kulttischchen der Lengyel-Kultur im mittel- und südosteuropäischen Neolithikum. Acta Archaeologica Academiae Scientiarum Hungaricae 61, 307-385.

ZALAI-GAÁl, I. - OszTÁs, A. - KöHLeR, K. 2012: Ein Neuer Gefässtyp der Spätlengyel-Kultur von Alsónyék-Bátaszék, Südtransdanubien. In: VAssıL, N. (ed.), Internationales Humboldt-Kolleg: "Der Schwarzmeerraum vom Neolithikum bis in die Früheisenzeit (6000 - 600 v.Chr.): Kulturelle Interferenzen in der Zirkumpontischen Zone und Kontakte mit ihren Nachbargebieten". (Varna, Bulgarien, 16. - 20. Mai 2012). In press.

Zalai-GaÁl, I. - Osztás, A. - Köhler, K. 2012: Totenbrett oder Totenhütte? Zur Struktur der lengyelzeitlichen Gräber mit Pfostenstellung Südtransdanubiens. Acta Archaeologica Academiae Scientiarum Hungaricae 63, 69-116. 


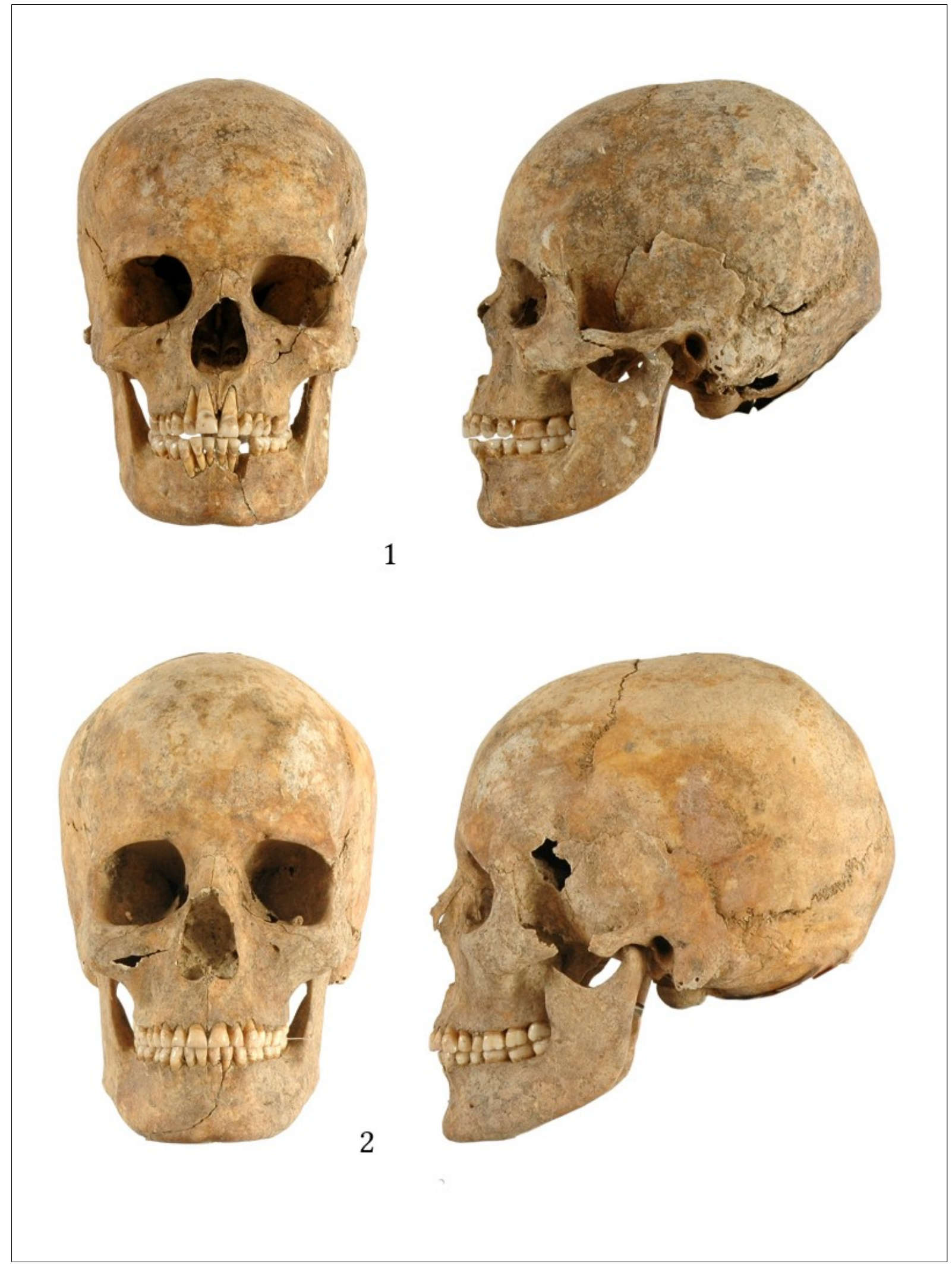

Fig. 8. The dominate skulls in the Alsónyék series (F. Fazekas). 1. Skull No. 115. (Gracile Mediterranean type) 2. Skull No. 768. (Gracile Mediterranean type). 


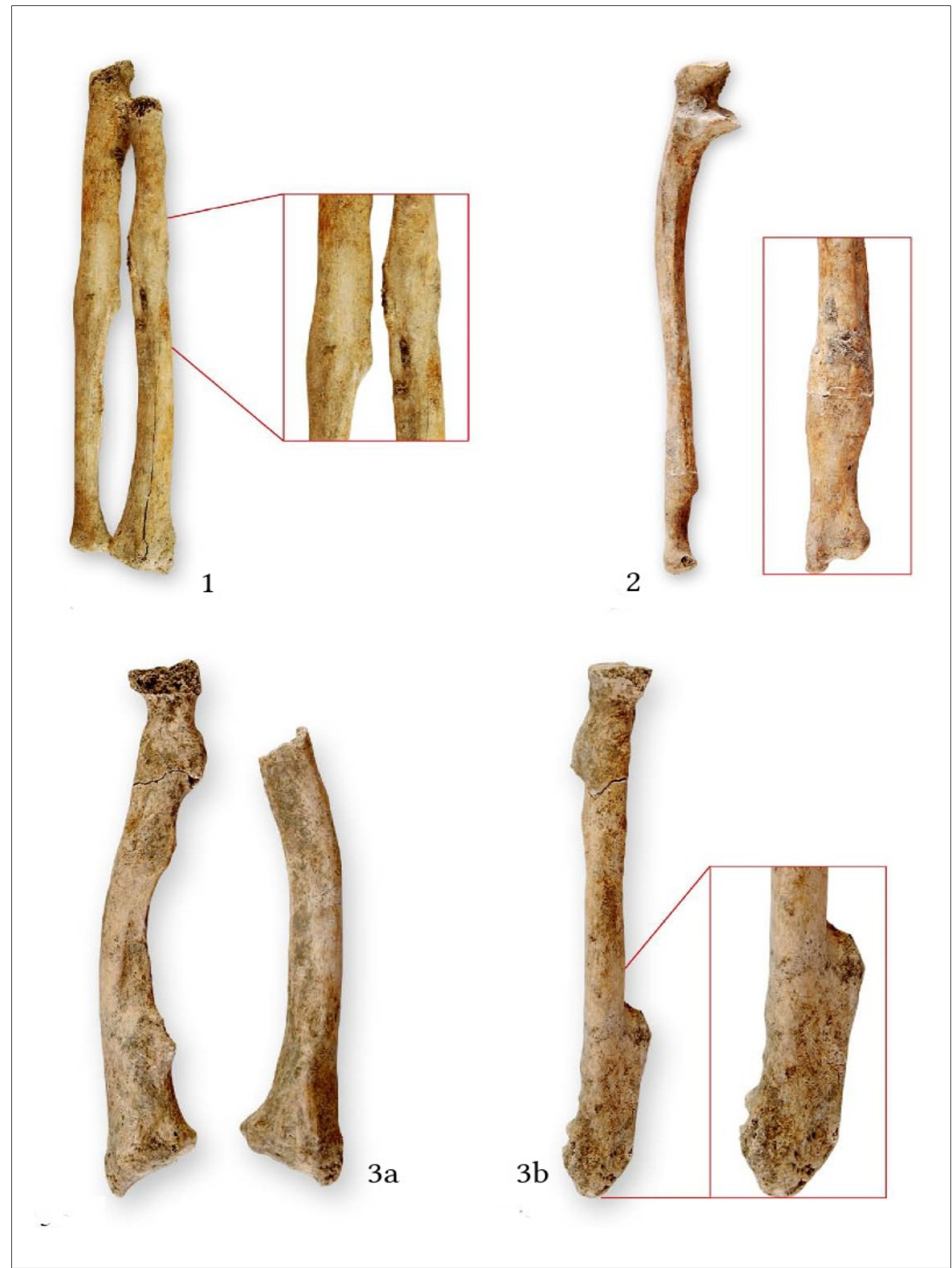

Fig. 9. Rare pathological altertions: Fractures (F. Fazekas). 1. Left sided ulna and radius (Grave No. 369). 2. Right sided ulna (Grave No 848). 3. a-b. Right sided radius (Grave No. 6052). 


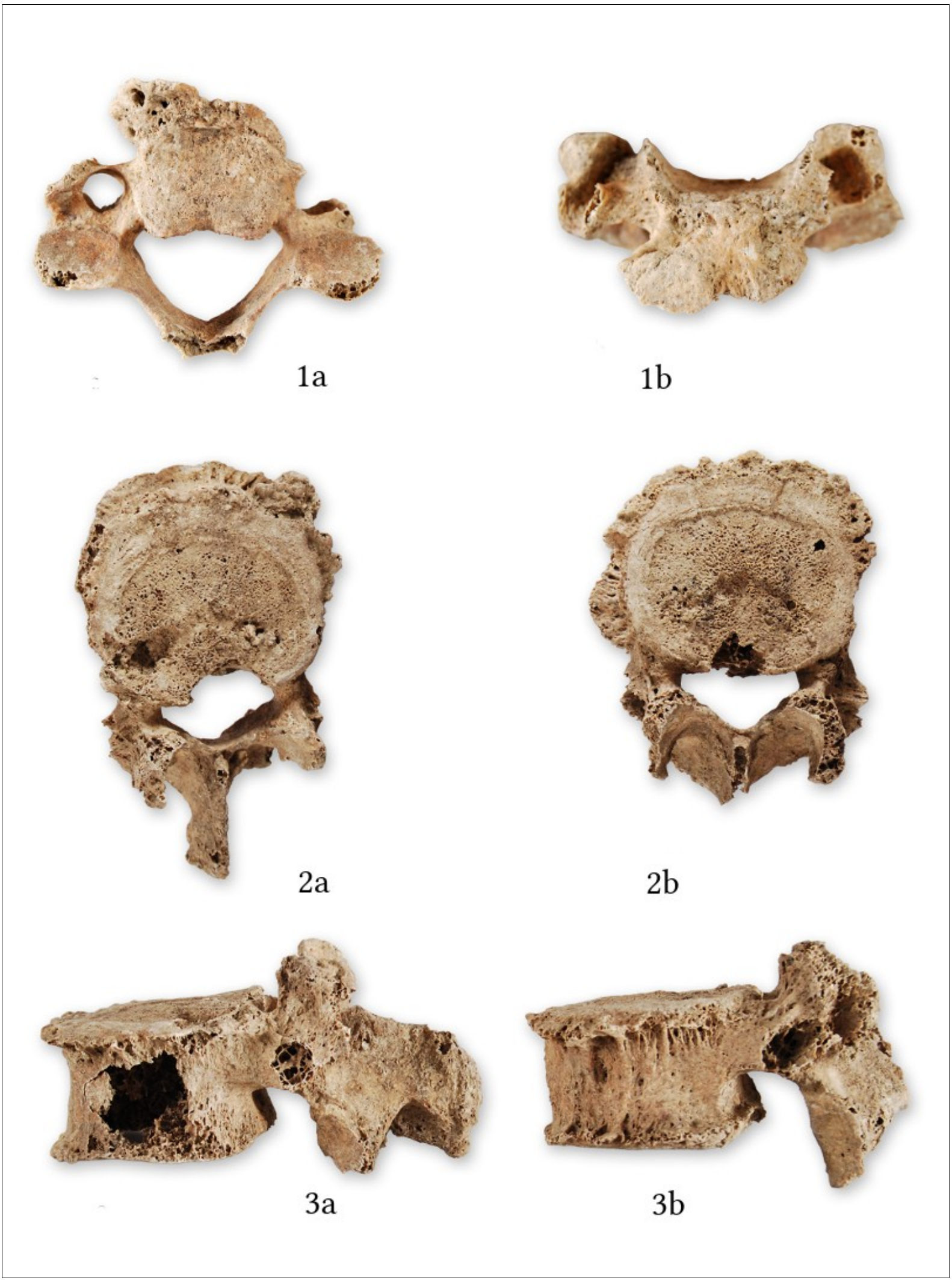

Fig. 10. Rare pathological altertions: Spondylosis deformans (F. Fazekas). 1.a-b. Severe osteophyte formation on the cervical vertebrae (Grave No. 715). 2. a-b. Moderate osteophyte formation on the lumbar vertebrae. Top view (Grave No. 715). 3. a-b. Moderate osteophyte formation on the lumbar vertebrae. Lateral view (Grave No. 715). 


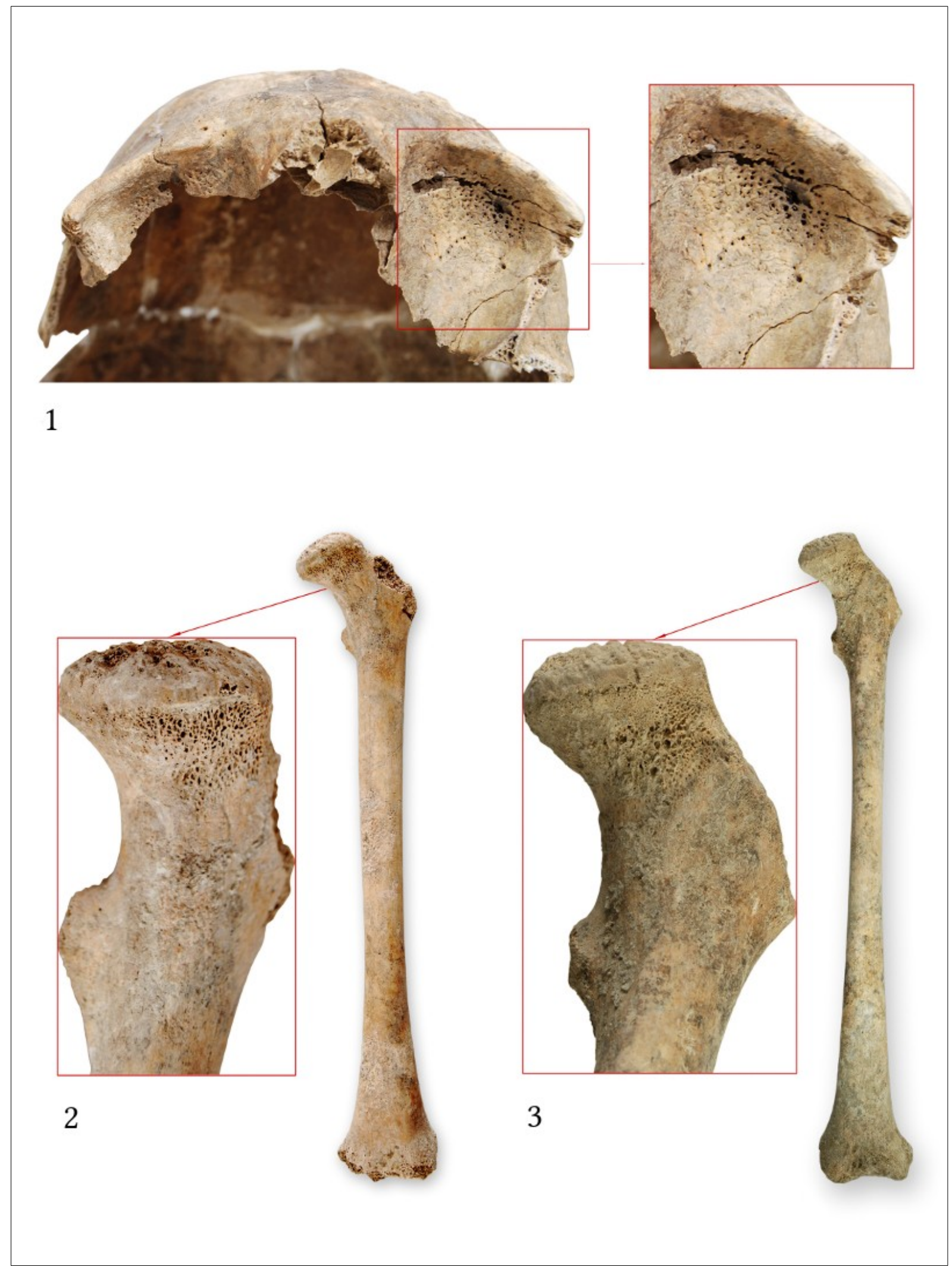

Fig. 11. Frequently occured diseases: Porotic Hyperostosis (F. Fazekas). 1. Cribra orbitalia in the upper part of the orbita (Grave No. 813). 2. Porotic Hyperostosis on the left sided neck of the femur (Grave No. 4981). 3. Porotic Hyperostosis on the left sided neck of the femur (Grave No. 767). 


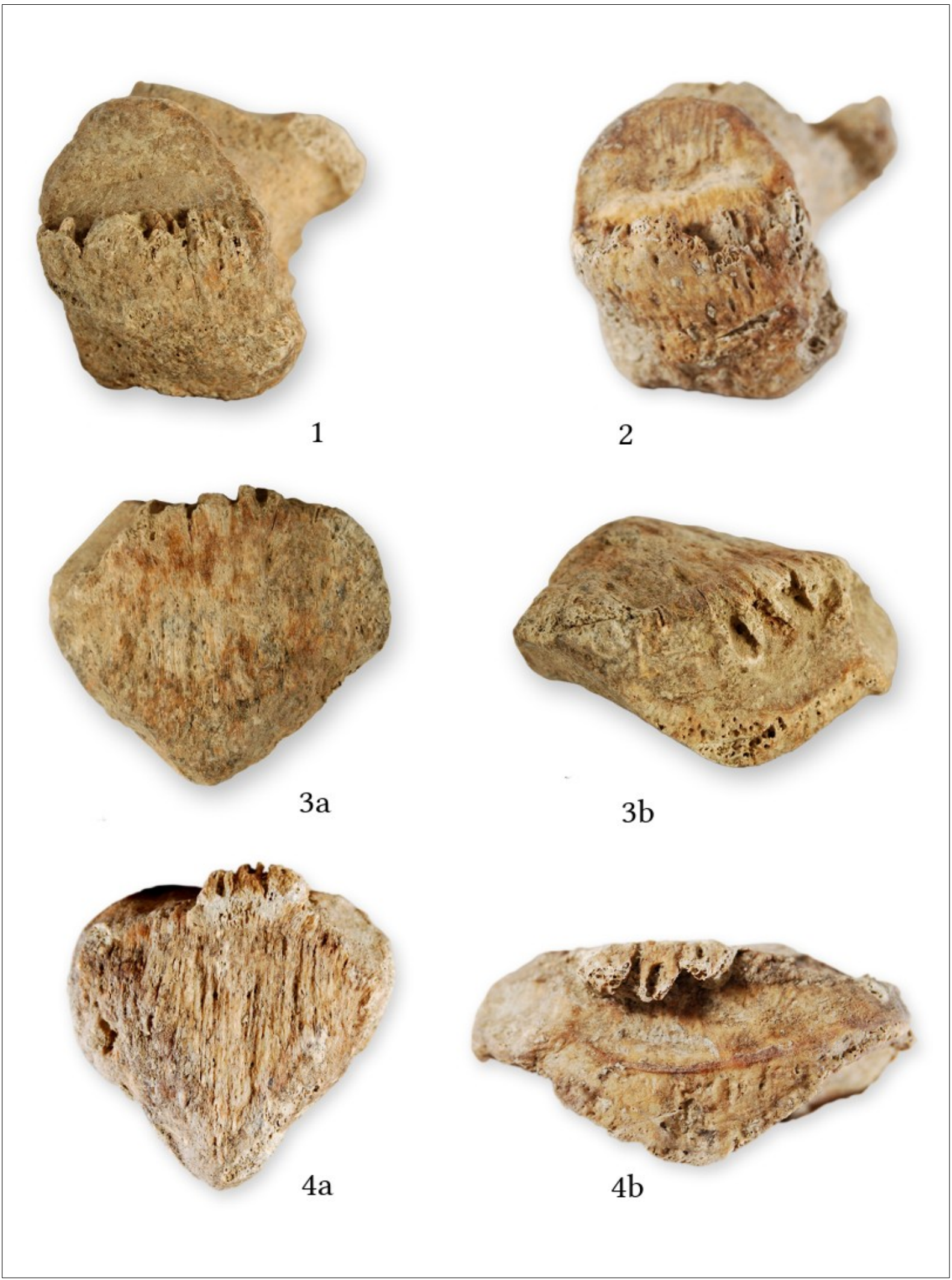

Fig. 12. Frequently occured diseases: Enthesopathic deformities (F. Fazekas). 1. Moderate enthesopathy on a calcaneum (Grave No. 500). 2. Moderate enthesopathy on a calcaneum (Grave No. 880). 3. Severe enthesopathy on a patella (Grave No. 500). 4. Severe enthesopathy on a patella (Grave No. 880). 


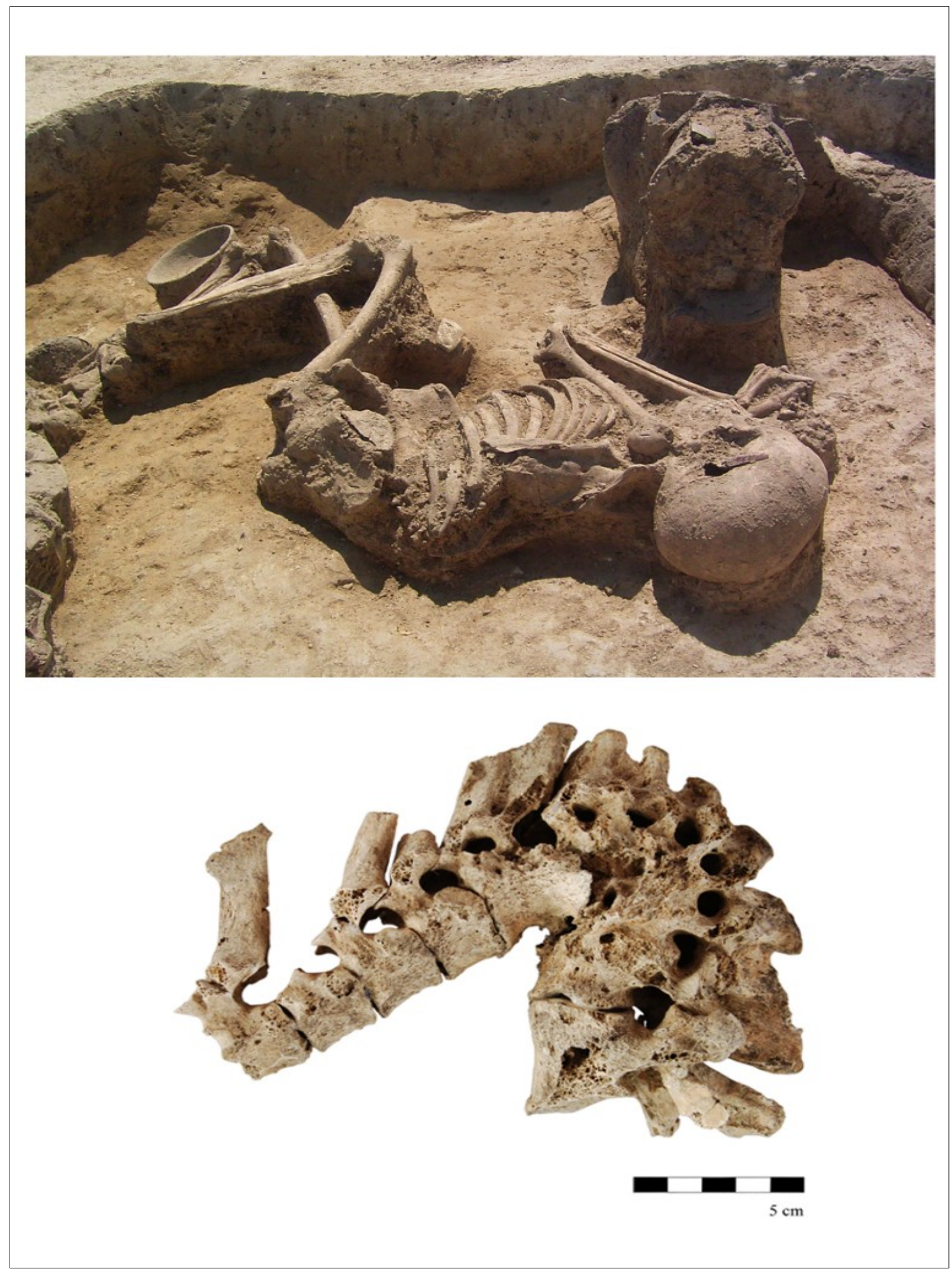

Fig. 13. Tuberculosis, Grave No. 4027. (Archeosztráda Ltd - F. Fazekas) Excavation photo (above). The severe curvate of the spine is well observable. The TB affected spine (below), where the curve, the collapse and the fusion of the affected vertebrae (Pott--gibbus) are well observable. 